\title{
Cross-presentation of cell-associated antigens by mouse splenic dendritic cell populations
}

\section{Robert I. Thacker and Edith M. Janssen*}

Division of Molecular Immunology, Cincinnati Children's Hospital Research Foundation, University of Cincinnati College of Medicine, Cincinnati, OH, USA

\section{Edited by:}

Christian Kurts,

Friedrich-Wilhelms-Universität Bonn, Germany

Reviewed by:

Daniel Robert Engel, University Clinic of Bonn, Germany

Carlos Ardavin, Centro Nacional de Biotecnologia/Consejo Superior de Investigaciones Científicas, Spain

*Correspondence:

Edith M. Janssen, Division of Molecular Immunology, Cincinnati Children's Hospital Research Foundation, University of Cincinnati College of Medicine, Room S5.419, 3333 Burnet Avenue, Cincinnati, $\mathrm{OH}$ 45229, USA.

e-mail: edith.janssen@cchmc.org
Cross-presentation of cell-associated antigens (Ag) plays an important role in the induction of anti-tumor responses, autoimmune diseases, and transplant rejection. While several dendritic cell (DC) populations can induce pro-inflammatory $\mathrm{CD}^{+}{ }^{+} \mathrm{T}$ cell responses to cellassociated Ag during infection, in the absence of infection, cross-priming of naïve $\mathrm{CD} 8^{+} \mathrm{T}$ cells is highly restricted. Comparison of the main splenic DC populations in mice - including the classic, cross-presenting CD8 $\alpha \mathrm{DC}$ and the recently described merocytic $\mathrm{DC}(\mathrm{mcDC})-$ reveals that cross-priming DCs display a distinct phenotype in cell-associated Ag uptake, endosomal/lysosomal trafficking, lysosomal acidification, and Ag persistence compared to non-cross-priming DC populations. Although the CD8 $\alpha$ DC and mcDC subsets utilize similar processing pathways to cross-present cell-associated Ag, cross-priming by CD8 $\alpha$ DCs is associated with IL-12 production, while the superior priming of the $\mathrm{mcDC}$ is critically dependent on type I IFN production. This discussion illustrates how subtle differences in internal processing pathways and their signaling sequelae significantly affect the duration of Ag cross-presentation and cytokine production by DCs, thereby shaping the ensuing $\mathrm{CD}^{+} \mathrm{T}$ cell response.

Keywords: dendritic cell, cross-presentation, cell-associated antigen, type I IFN, antigen processing

\section{INTRODUCTION}

Every day millions of cells die in the human body, producing cellular corpses and material that must be disposed of. Dead cells originating from the body's surfaces can simply be sloughed off with little or no consequence. In contrast, cells that die within tissues must be removed, a task typically undertaken by phagocytic cells of the immune system. This system has dual purpose. If the cell death is necrotic, due to viral or bacterial infection, the clearance of diseased cells assists in removing the insult and activating specific immunity against the offending cell-associated Ag. If the cell death is a part of natural tissue homeostasis, i.e., apoptotic cell death, the clearance of dead cells can function to maintain peripheral tolerance and prevent autoimmune disease. Within this context apoptotic cell death is historically considered an immunologically silent event.

Though seemingly simple in concept, continuing research on apoptosis and the clearance of apoptotic cells has revealed the complexity of this system. As a result, a multitude of factors have been identified that influence whether tolerance or immunity is established against cell-associated Ag upon uptake of apoptotic cells. These factors include, but are not limited to, the type of cell that is dying, how death was induced, in which tissue the death occurred, the recognition and uptake by phagocytic cells, the type of phagocyte involved in the uptake, and the resulting micro-environment (Poon et al., 2010). For example, cells treated with irradiation or chemotherapy become apoptotic but tend to be immunogenic (Ronchetti et al., 1999; Janssen et al., 2006; Green et al., 2009; Reboulet et al., 2010; Ferguson et al., 2011). In this context immunity probably results from the irradiation or chemical induced release of damage associated molecular proteins (DAMPS) such as high mobility group box 1 (HMGB1), uric acid/mono-sodium urate crystals, heat shock proteins, and nucleotide structures from the dying cell (Green et al., 2009; Poon et al., 2010). These signals, similar to those released during necrotic cell death, provoke immunity instead of tolerance. Though important, signals released by the dying cell do not fully explain immunologic outcome. Studies wherein identically treated cells induce tolerance if injected intravenously, yet immunity if injected subcutaneously illustrated how the location of cell death and, more importantly, the type of antigen presenting cell (APC) performing the uptake crucially affect immunity or tolerance. Subsequent studies correlated this induction of immunity or tolerance specifically with the dendritic cell (DC) subset that took up and processed the injected cells (Belz et al., 2002; Ferguson et al., 2002; Iyoda et al., 2002; Green et al., 2009).

\section{DENDRITIC CELLS AND THE PRESENTATION OF CELL-ASSOCIATED ANTIGENS}

In the evolution of the vertebrate immune system, DCs have filled the role of premier APC. All APCs characteristically take up, process and present exogenous antigens to $\mathrm{CD}^{+}{ }^{+} \mathrm{T}$ cells within the context of MHC class II molecules. Uniquely, DCs are additionally able to shuttle a portion of "eaten" antigens into the MHC class I restricted pathway, a pathway that in all other cell types is reserved for presentation of endogenous proteins. In DCs, this cross-presentation process allows exogenous Ag, including cell-associated Ag originating from dead and dying cells, to be effectively presented to $\mathrm{CD}^{+} \mathrm{T}$ cells. Seminal work over the last decade addressing uptake and processing of cell-associated Ag by phagocytes has elucidated common 
mechanisms utilized by cross-presenting DC subsets that influence cross-presentation and the resulting immune response. Successful cross-presentation is characterized by specific uptake, distinct endosomal/lysosomal trafficking, delayed lysosomal acidification, and Ag persistence compared to non-cross-priming DC populations. Also, the cytokine profile by which each DC subset responds to uptake of dying cells influences these processes and the final potency of the Ag-specific response.

\section{MOUSE SPLENIC DC SUBSETS DURING STEADY STATE}

As a result of ongoing research, the system by which DCs are classified continues to change. Currently, as new subsets are discovered, characterization often places them into one of two groups: steady state conventional DCs (cDCs) or non-conventional DCs (Kushwah and $\mathrm{Hu}, 2011$ ). This initial classification is based on lineage, function, and location, with each subset being identified by the presence or absence of different cell surface markers. Steady state cDCs, as the name suggests, are present and function continually, even during inflammation, and include subsets found in the lymphoid organs as well as migratory subsets present in the tissues. Non-conventional DCs are mostly comprised of monocytederived DCs subsets, populations which are highly enriched during inflammation and thus are often referred to as inflammatory DCs (Shortman and Liu, 2002; Heath et al., 2004; Shortman and Naik, 2007; Liu et al., 2009; Kushwah and Hu, 2011). DCs found in non-lymphoid tissue regardless of whether formally categorized as steady state conventional or monocyte-derived non-conventional, are typically classified by the tissue in which they are found and the presence or absence of CD103, CD11b, langerin (for skin associated subsets), or the chemokine receptor CX3CR1 (Kushwah and $\mathrm{Hu}, 2011$ ). Though some of these subsets are capable of crosspresentation, this review focuses on those subsets present in the spleen. We refer those interested to several publications that more completely dissect the lineages, functionality and surface expression of various markers in these other DC populations (Shortman and Liu, 2002; Heath et al., 2004; Shortman and Naik, 2007; Liu et al., 2009; del Rio et al., 2010; Liu and Nussenzweig, 2010; Shortman and Heath, 2010; Kushwah and Hu, 2011). Plasmacytoid DCs (pDCs), a subset also present in the spleen during steady state, are functionally distinct from both cDCs and non-conventional subsets, but possess a common precursor with cDCs subsets. In spite of this connected lineage, functional differences between cDCs and pDCs complicates the exact placement of the latter subset and, thus, has led to controversy. As a result, some researchers place $\mathrm{pDCs}$ with non-conventional DCs while others place them within a distinct group called pre-DCs or within their own category (Shortman and Liu, 2002; Shortman and Naik, 2007; Liu and Nussenzweig, 2010; Kushwah and Hu, 2011).

Conventional DCs and pDCs present in spleen and lymph nodes are distinguished by differential expression of CD11c, B220, and PDCA-1. Splenic cDCs lack B220 and PDCA-1 (Figure 1A) and can be further divided into four subpopulations characterized by the presence or lack of various markers (Table 1): (1) $\mathrm{CD} 8 \alpha \mathrm{DCs}\left(\mathrm{CD} 8 \alpha^{+}, \mathrm{CD} 4^{-}, \mathrm{CD} 11 \mathrm{~b}^{-}\right)$; (2) CD11b DCs $\left(\mathrm{CD} 8^{-}\right.$, $\left.\mathrm{CD}^{-}, \mathrm{CD}_{11 \mathrm{~b}^{+}}\right)$; (3) CD4 DCs $\left(\mathrm{CD} 8^{-}, \mathrm{CD}^{+}, \mathrm{CD} 1 \mathrm{~b}^{+}\right)$; or $(4)$ merocytic DCs (mcDCs)/CD8 ${ }^{-}, \mathrm{CD}^{-}, \mathrm{CD} 11 \mathrm{~b}^{-} \mathrm{DC}$ (Figure 1A; Janssen et al., 2006; Reboulet et al., 2010; Shortman and Heath,

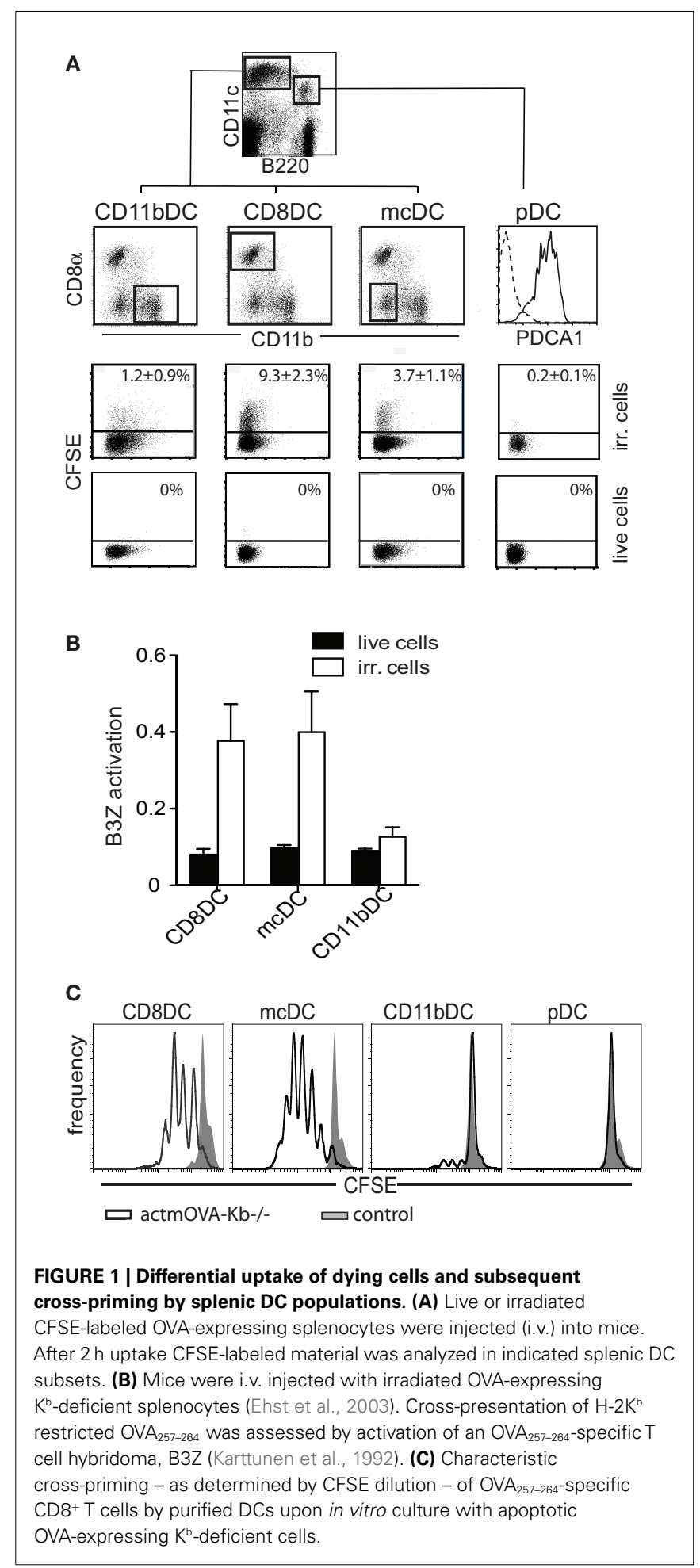

2010; Hennies et al., 2011; Kushwah and Hu, 2011). We have investigated, and thus will discuss in this review, the uptake of cell-associated Ag under steady state conditions and their crosspresentation within four splenic DC subgroups - CD8 $\alpha$ DCs, CD11b DCs (which includes the $\mathrm{CD}^{+}{ }^{+}$subset), $\mathrm{mcDC} / \mathrm{CD} 8^{-}$,

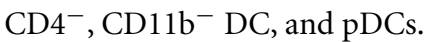


Table 1 | Characteristics of splenic DC subsets.

\begin{tabular}{|c|c|c|c|c|c|}
\hline & $\mathrm{CD}^{+} \mathrm{DC}$ & $\mathrm{CD}_{11 \mathrm{~b}}+\mathrm{DC}$ & $\mathrm{CD8}^{-} \mathrm{CD}^{-} \mathrm{mcDC}$ & pDC & Reference \\
\hline Itgax/CD11c & +++ & +++ & +++ & ++ & Hashimoto et al. (2011) \\
\hline itgam/CD11b & - & +++ & + & - & Vremec et al. (2000), Vremec and Shortman (1997) \\
\hline Sirpa/CD172a & $-1+$ & +++ & $-/+$ & $+1-$ & Lahoud et al. (2006) \\
\hline CD4 & - & ++ & - & - & Crowley et al. (1989), Vremec et al. (2000) \\
\hline CD8a & +++ & - & - & - & Shortman and Heath (2010) \\
\hline itgae/CD103 & ++ & - & - & - & Bedoui et al. (2009b), McLellan et al. (2002), Qiu et al. (2009) \\
\hline CD205 & ++ & - & $-/+$ & - & Kraal et al. (1986), Shrimpton et al. (2009) \\
\hline XCR1 & ++ & - & + & - & Crozat et al. (2011), Robbins et al. (2008) \\
\hline IRF8 & ++ & - & ++ & ++ & Aliberti et al. (2003), Schiavoni et al. (2002), Tailor et al. (2008) \\
\hline IRF4 & $-/+$ & ++ & $-1+$ & $-1+$ & Hashimoto et al. (2011) \\
\hline$M H C / /$ & +++ & +++ & +++ & ++ & Wilson et al. (2003) \\
\hline CD80 & + & + & + & - & Shortman and Heath (2010), Wilson et al. (2003) \\
\hline CD86 & ++ & + & ++ & $+1-$ & Shortman and Heath (2010) \\
\hline CD40 & + & ++ & + & + & Shortman and Heath (2010) \\
\hline TLR3 & +++ & + & +++ & - & Edwards et al. (2003) \\
\hline$T L R 7$ & - & + & - & ++ & Edwards et al. (2003) \\
\hline TLR9 & + & + & + & ++ & Edwards et al. (2003) \\
\hline Clec9a & +++ & + & +++ & + & Sancho et al. (2008) \\
\hline CLec12a & +++ & + & nd & nd & Lahoud et al. (2009) \\
\hline Havcr1/tim1 & - & - & - & +++ & Kobayashi et al. (2007) \\
\hline Havcr2/tim3 & +++ & +++ & +++ & - & Nakayama et al. (2009) \\
\hline Tim 4 & + & $+1-$ & + & + & Albacker et al. (2010), Kobayashi et al. (2007) \\
\hline Treml2 & + & + & ++ & +++ & Hemmi et al. (2009) \\
\hline Treml4 & +++ & ++ & ++ & - & Hemmi et al. (2009) \\
\hline CD36 & +++ & ++ & +++ & $+1-$ & Albert et al. (1998) \\
\hline MR & - & + & - & - & Burgdorf et al. (2006), Burgdorf et al. (2008), Sallusto et al. (1995) \\
\hline Lox1 & + & - & + & - & Delneste et al. (2002), Erwig and Henson (2008), Oka et al. (1998) \\
\hline Fc $\gamma R 2 b$ & + & ++ & + & + & Amigorena (2002), Rodriguez et al. (1999) \\
\hline Cystatin C & ++ & + & ++ & + & El-Sukkari et al. (2003) \\
\hline NOX2 gpphox91 & $+1-$ & ++ & + & nd & Savina et al. (2006) \\
\hline \multicolumn{6}{|c|}{ CYTOKINE INDUCTION UPON UPTAKE OF APOPTOTIC CELLS } \\
\hline $\mathrm{IL}-12$ & - & - & - & - & Morelli et al. (2003) \\
\hline $\mathrm{IL}-10$ & - & ++ & - & - & Hennies et al. (2011) \\
\hline $\mathrm{TGF} \beta$ & $+1-$ & ++ & - & - & Hennies et al. (2011), Yamazaki et al. (2008) \\
\hline Type I IFN & - & - & ++ & - & Janssen et al. (2006), Lorenzi et al. (2011) \\
\hline
\end{tabular}

Data compiled from indicated literature and unpublished DNA arrays. nd, not done.

\section{CD8 $\alpha$ DCs}

The CD $8 \alpha$ DC, classically considered to be the major crosspresenting DC subset in the mouse spleen, is located in the $\mathrm{T}$ cell zone of the spleen and has repeatedly been shown to effectively cross-present beads, soluble Ag, and cell-associated Ag (Figures 1B,C; den Haan et al., 2000; Pooley et al., 2001; Heath et al., 2004; Belz et al., 2005; Schnorrer et al., 2006). The development of CD8 $\alpha$ DCs is dependent on Flt3L-STAT3 signaling. While $\mathrm{cDC}$ development in general requires the transcription factors Ikaros, and PU.1 (Wu et al., 1997; Anderson et al., 2000; Guerriero et al., 2000; Allman et al., 2006; Wu and Liu, 2007), the CD8 $\alpha$ DC lineage commitment is also dependent on Batf3, IRF-8, and Id2 (Schiavoni et al., 2002; Hacker et al., 2003; Hildner et al., 2008). This DC subset, in addition to being CD8 $\alpha^{+}$, also expresses DEC205, XCR1, and Clec9a (Vremec et al., 2000; Sancho et al.,
2009; Shortman and Heath, 2010; Crozat et al., 2011). Depending on age and strain of mouse, up to $70 \%$ of CD8 $\alpha$ DCs co-express CD103, which has been suggested to represent a developmental stage or activation state within the CD $8 \alpha$ DC population or a $\mathrm{CD}^{+}$subset with distinct functionality (Pribila et al., 2004; Qiu et al., 2009; del Rio et al., 2010; Shortman and Heath, 2010). CD8 $\alpha$ DCs take up dead cells more readily than other splenic DC subsets (Figure 1A; Iyoda et al., 2002; Schulz and Reis e Sousa, 2002; Schnorrer et al., 2006) and have been implicated in the induction and maintenance of $\mathrm{CD} 8^{+} \mathrm{T}$ cell tolerance to cell-associated $\mathrm{Ag}$ in models of autoimmunity and transplantation (Kurts et al., 1996, 1998; Hawiger et al., 2001; Belz et al., 2002; Bonifaz et al., 2002; Scheinecker et al., 2002; Shortman and Heath, 2010). This subset's importance in the cross-presentation of cell-associated Ag is further supported by a dramatic reduction of anti-tumor immunity 
in mice deficient in Batf3, a gene crucial for the development of the CD8 $\alpha$ DC precursor (Hildner et al., 2008).

\section{CD11b DCs}

Splenic CD11b DCs reside in the marginal zone of the spleen and predominantly co-express CD4, DCIR2, and Sirp- $\alpha$ (Crowley et al., 1989; Pulendran et al., 1997; Maldonado-Lopez and Moser, 2001; Lahoud et al., 2006). CD11b DC development is governed by transcription factors IRF2/4 (Honda et al., 2004; Ichikawa et al., 2004; Suzuki et al., 2004) and RelB (Burkly et al., 1995; Weih et al., 1995; Wu et al., 1998).

While CD11b DCs display great potential for phagocytosis of proteins, beads/particles, and bacteria, their capacity for crosspresentation under steady state conditions is poor. Moreover, CD11b DCs display weak phagocytosis of apoptotic cells and no role has been described for these cells in cross-presentation to cellassociated Ag under steady state conditions (Figures 1A-C; den Haan et al., 2000; Pooley et al., 2001; Iyoda et al., 2002; Schulz and Reis e Sousa, 2002; Morelli et al., 2003; Schnorrer et al., 2006).

\section{PLASMACYTOID DENDRITIC CELLS}

Splenic pDCs are defined by strong expression of both B220 and PDCA- 1 and are predominantly located in the $\mathrm{T}$ cell area and red pulp. While there is some discussion on the exact delineation of pDC with regard to shared precursors with other $\mathrm{CDC}$, research has shown the requirement for the transcription factors E2-2, IRF8, and Spi-B (Schiavoni et al., 2002; Schotte et al., 2004; Cisse et al., 2008). Although pDCs are poor at taking up cell-associated Ag, depletion studies have shown that $\mathrm{pDCs}$ are critical in the induction of tolerance after intravenous injection of apoptotic cells. Such tolerance, however, does not require direct pDC-apoptotic cell interactions, but rather soluble mediators from marginal zone macrophages (Bonnefoy et al., 2011).

\section{MEROCYTIC DCs/CD8- ${ }^{-}$CD4 $^{-}$, CD11b- DC $^{-}$}

Over the recent years various laboratories have identified splenic DCs that lack the conventional markers $\left(\mathrm{CD} 8 \alpha^{-}, \mathrm{CD}_{11 \mathrm{~b}}^{-}, \mathrm{CD} 4^{-}\right.$; Figures 1A-C; Hochrein et al., 2001; Naik et al., 2005; Janssen et al., 2006; Vremec et al., 2007; Bedoui et al., 2009a; Katz et al., 2010; Reboulet et al., 2010; Hennies et al., 2011). Generally, these populations are relatively small and only comprise $<1-10 \%$ of the DC in a naïve steady state spleen. Several of these DC populations have been shown to cross-present antigens in protein (Vremec et al., 2007) or cell-associated form (Bedoui et al., 2009a; Reboulet et al., 2010; Hennies et al., 2011). Flt3L treatment of mice significantly increases the frequency of these DCs, and cells with similar features can be generated by in vitro Flt3L bone-marrow cultures (Bedoui et al., 2009a; Reboulet et al., 2010; Hennies et al., 2011).

During the course of our work we have named the CD8 $\alpha^{-}$

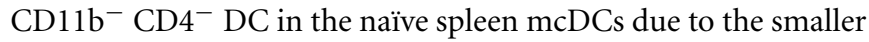
particles $($ meros $=$ particle) characteristically taken up by these cells (Figure 2C) and will use this name throughout this review (Reboulet et al., 2010). Like CD8 $\alpha$ DCs, mcDCs express XCR1, Clec9a, and are Sirp- $\alpha$ negative, but in contrast are DEC205 ${ }^{-}$, $\mathrm{CD} 103^{-}$, and $\mathrm{CD} 11 \mathrm{~b}^{-/ \text {dull }}$ (Table 1). It has been suggested that this marker negative subset is a precursor to the CD $8 \alpha$ DCs (Janssen et al., 2006; Bedoui et al., 2009a), a hypothesis supported by the presence of Clec9a and CD24, surface molecules shown to be present on the immediate precursors of CD8 $\alpha$ DCs that lack CD8 and DEC205 expression (Sathe and Shortman, 2008; Shortman and Heath, 2010; Kushwah and Hu, 2011). CD8 $\alpha^{-}$CD11b $^{-}$ $\mathrm{CD}^{-}$DC obtained from Flt3L treated mice readily convert into CD8 $\alpha$ DCs upon transfer (Bedoui et al., 2009a). However, only a small fraction of $\mathrm{CD} 8 \alpha^{-} \mathrm{CD}_{11} \mathrm{~b}^{-} \mathrm{CD} 4^{-} \mathrm{DC} / \mathrm{mcDC}$ from naïve spleens convert to CD8 $\alpha$ DCs (Reboulet et al., 2010) suggesting that mcDCs are either "long-term" CD8 $\alpha$ DC precursors that are relatively resistant to conversion or a stable population that possesses unique functionality and marker expression compared to other known precursors.

Merocytic DCs take up cellular material from dead and dying cells, though be it less than CD8 $\alpha$ DCs (Figure 1A). Though mcDCs take up less apoptotic cell material they show extended cross-priming of $\mathrm{CD}^{+} \mathrm{T}$ cells due to prolonged storage of cellassociated Ag (Reboulet et al., 2010). Importantly, mcDCs prime both $\mathrm{CD}^{+}$and $\mathrm{CD}^{+}{ }^{+}$T cells to cell-associated Ag (Figures 1B,C; Janssen et al., 2006; Reboulet et al., 2010). CD4 ${ }^{+}$T cell activation is important in the induction of immunity against cell-associated $\mathrm{Ag}$ as $\mathrm{CD}^{+} \mathrm{T}$ cells become tolerant without sufficient $\mathrm{CD} 4^{+} \mathrm{T}$ cell help (Janssen et al., 2003, 2005; Griffith et al., 2007). CD8 ${ }^{+} \mathrm{T}$ cells primed by mcDC to cell-associated Ag show greater capacity for primary expansion, cytokine production, and memory formation on a per cell basis than those primed by CD8 $\alpha$ DC (Janssen et al., 2006; Katz et al., 2010; Reboulet et al., 2010; Hennies et al., 2011).

Merocytic DC have been associated with the breaking of tolerance and acceleration of immune responses to cell-associated Ags. Treatment of tumor bearing mice with $\mathrm{mcDC}$ previously exposed to irradiated tumor cells, resulted in tumor suppression and increased host survival through the activation of naïve tumorspecific $\mathrm{CD} 8^{+} \mathrm{T}$ cells as well as the reinvigoration of tumor-specific $\mathrm{T}$ cells that had been rendered non-responsive by the tumor in vivo (Reboulet et al., 2010). Dysregulation of the mcDC compartment has also been associated with the development of autoimmunity; mcDCs are more numerous and more biologically active in the non-obese diabetic (NOD) mouse model of type I diabetes and absolute numbers correlate with disease development and progression. Transfer of mcDCs - loaded with irradiated islet cellstransferred diabetes in young NOD recipients. Moreover, when purified from the pancreatic lymph nodes of overtly diabetic NOD mice, mcDCs break peripheral tolerance to beta antigens in vivo and induce the rapid onset of T cell-mediated type I diabetes in young NOD mice (Katz et al., 2010).

\section{RECOGNITION AND DIFFERENTIAL UPTAKE OF DEAD AND DYING CELLS}

Though little is known regarding the influence of clathrinmediated uptake vs. phagocytosis or macropinocytosis on crosspresentation pathways of cell-associated Ag, uptake and crosspresentation of cellular material is largely thought to be receptor mediated (Erwig and Henson, 2008).

\section{RECOGNITION THROUGH PHAGOCYTIC RECEPTORS}

As a cell becomes apoptotic, the steady state "don't eat me" signals of viable cells are lost and replaced through a series of 
A

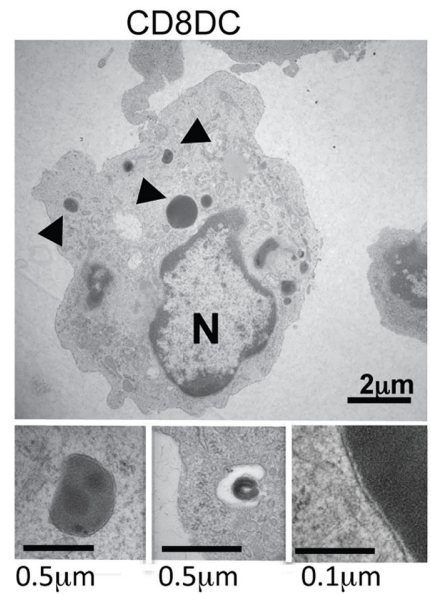

B

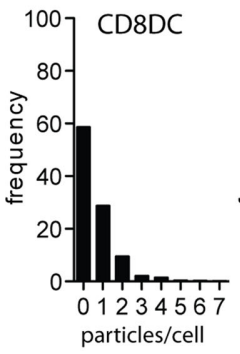

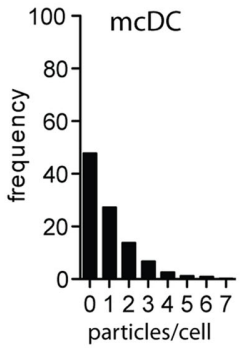

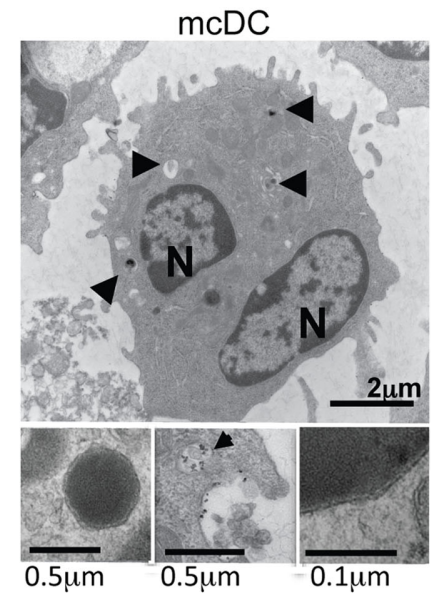

$2 u \mathrm{~m}$
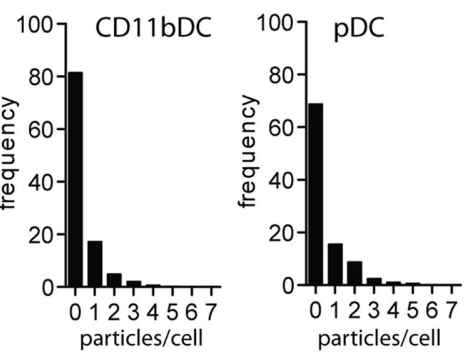

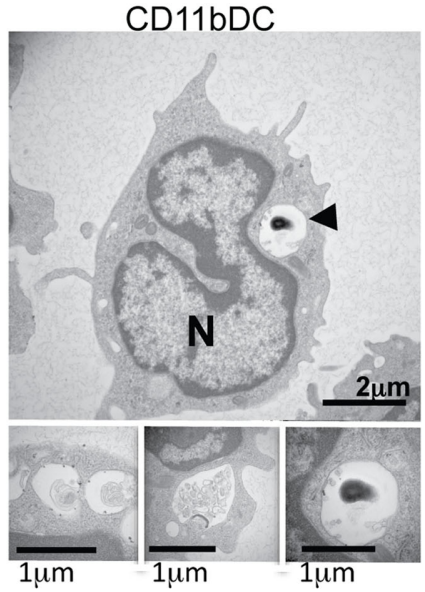

C

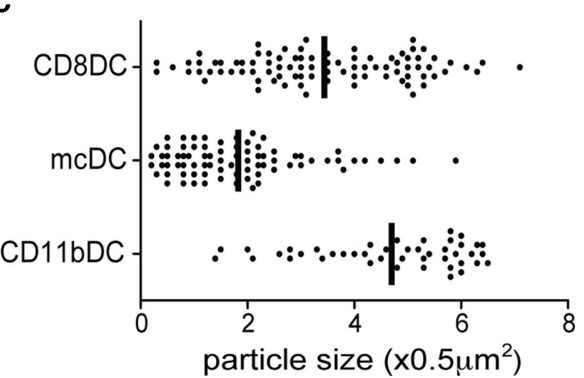

FIGURE 2 | Splenic DC subsets differentially take up cellular particles influencing particle frequency and size. (A) Transmission electron

microscopy (TEM) images characterizing uptake of irradiated splenocytes by purified DC subsets after $4 \mathrm{~h}$ co-culture: $\mathrm{N}$, nucleus; arrows, apoptotic material. (B,C) ImageStream analysis of the frequency and size of internalized CFSE-labeled particles after $20 \mathrm{~h}$ co-culture with CFSE-labeled irradiated cells. morphological and biochemical changes (Elward and Gasque, 2003; Erwig and Henson, 2008; Poon et al., 2010). The most prominent and perhaps best-characterized change is the exposure of phosphatidylserine (PS) on the surface of the dying cell. Once PS is exposed, it can be recognized by a number of bridging molecules including milk fat globular-EGF factor 8 protein (MFG-E8; Borisenko et al., 2004; Hanayama et al., 2004), growth arrest-specific 6 (Gas6; Ishimoto et al., 2000; Scott et al., 2001), $\beta 2$ glycoprotein I ( $\beta 2-G P I ;$ Balasubramanian et al., 1997), and serum Protein S (Erwig and Henson, 2008; Krysko and Vandenabeele, 2008; Poon et al., 2010). Many of these bridging molecules then facilitate recognition by receptors on the surface of the phagocyte, including the integrins $\alpha \mathrm{v} \beta 3$ or $\alpha \mathrm{v} \beta 5$ (Borisenko et al., 2004; Hanayama et al., 2004; Erwig and Henson, 2008). Additionally, the apoptotic cell and other bridging molecules like TSP-1 are recognized by phagocytic receptors such as Tim-1, Tim-3, and Tim-4 (Kobayashi et al., 2007; Nakayama et al., 2009; Albacker et al., 2010), CD36 (Albert et al., 1998), Treml2 and Treml4 (Hemmi et al., 2009), DEC205 (Shrimpton et al., 2009), class A scavenger receptors (Platt et al., 2000), Lox-1 (Oka et al., 1998), and various C-type lectins including Clec9a (DNGR1; Krysko and Vandenabeele, 2008; Sancho et al., 2009; Poon et al., 2010; Shortman and Heath, 2010). While the seemingly overabundance of receptors involved in dying cell uptake stresses the importance of apoptotic cell removal in the maintenance of immune homeostasis, it is becoming apparent that these molecules are not merely redundant, but may distinctly influence APC behavior, and, thus, guide specific responses toward cell-associated antigens under various settings (Bratton and Henson, 2008; Erwig and Henson, 2008; Krysko and Vandenabeele, 2008).

Cross-presentation, but not necessarily cross-priming, of cellassociated $\mathrm{Ag}$ is generally enhanced when uptake is mediated by DEC205 (Bonifaz et al., 2002), Clec9a (Sancho et al., 2008, 2009), Lox-1(Delneste et al., 2002), or Fc gamma R (Regnault et al., 1999; Rodriguez et al., 1999; Amigorena, 2002; den Haan and Bevan, 2002; Kalergis and Ravetch, 2002; Flinsenberg et al., 2011). Uptake via the mannose receptor has also been implicated in cross-presentation pathways, but its relevance has thus far only been shown within the context of soluble Ag, not cell-associated Ag (Burgdorf et al., 2006, 2008). Comparison of the transcriptome of the four DC subsets suggests the most similarity between mcDCs and CD $8 \alpha$ DCs with regard to the expression of molecules involved in the recognition and uptake of dying cells. However, some receptors are still restricted to one subset - as is the case for DEC205 and CD $8 \alpha$ DCs - or have differential expression/different levels of expression, resulting in unique patterns for each subset (Table 1).

Consistent with receptor-mediated uptake leading to crosspresentation, both CD $8 \alpha$ DCs and mcDCs appear to take up cellular material via a classical receptor-mediated phagocytic process. Transmission electron microscopy (TEM) of CD8 $\alpha$ DCs and mcDCs exposed to dying cells predominantly shows the presence of small particles of phagocytosed material tightly surrounded by 
a double membrane (Figure 2A). In contrast, CD11b DCs appear to use a more macropinocytic mechanism resulting in the uptake of larger particles and inclusion of extracellular solutes and fluids (Figures 2A,C).

\section{PARTICLE SIZE AND FREQUENCY}

Our studies and the work of others indicate that the method of uptake, i.e., receptor-mediated phagocytosis vs. macropinocytosis, influences the particle size taken up by APCs (Rejman et al., 2004). While particle size determines the total amount of Ag available to the cell, a growing body of literature indicates that particle size also affects intracellular trafficking, the kinetics of phagosomal $\mathrm{pH}$, and thereby cross-presentation (Fifis et al., 2004; Rejman et al., 2004; Tran and Shen, 2009). Cross-presentation has been shown to be enhanced when $\mathrm{Ag}$ are bound onto particles between the range of 0.5 and $3 \mu$ (Tran and Shen, 2009). However, it is likely that the optimal size for cross-presentation will be affected by the composition of the particle, the receptors involved in the uptake and the nature of the cell.

Transmission electron microscopy combined with ImageStream technology, a flow cytometric based method that allows for quantitative image analysis on vast number of cells, confirmed that cross-presenting splenic DCs differentially take up material from dead and dying cells as measured by total particles per cell and the overall particle size. CD $8 \alpha$ DCs and mcDCs not only take up particles of dying cells more readily, but also preferentially take up smaller particles than CD11b DCs (Figures 2B,C), a size differential that most likely facilitates the entrance of cell-associated Ag into cross-presentation pathways (Fifis et al., 2004; Rejman et al., 2004; Tran and Shen, 2009).

Interestingly, upon exposure to dead and dying cells, mcDCs generally take up a comparable number of particles/cell to CD $8 \alpha$ DCs, but these particles are typically smaller in size (Figures 2B,C; Reboulet et al., 2010). While the mcDCs takes up a lower "net amount" of Ag, the smaller particle size might expedite the export to the cytosol which would facilitate Ag processing (Rodriguez et al., 1999; Rock et al., 2010).

\section{ANTIGEN TRAFFICKING, PROCESSING, AND LOADING ANTIGEN TRAFFICKING AND VESICLE ACIDIFICATION}

Upon uptake, cellular material from dying cells is found within early phagosomes - or sorting endosomes - characterized by the presence of the early endosomal markers EEA-1, Rab5, PI(3)P, syntaxin 13, transferrin, and vesicle-associated membrane protein 3(VAMP-3; Vieira et al., 2002; Peng and Elkon, 2011). The phagosome is transformed into a phagolysosome through a progressive maturation process that is dependent on the sequential fusion of endosomes and lysosomes with the internalized phagosome. Most recently this maturation process and antigen cross-presentation was shown to be regulated by the SNARE protein Sec22b through its control of ER-resident protein recruitment to phagosomes (Cebrian et al., 2011). Late endosomes/late phagosomes are associated with Rab7, Rab9, mannose 6-phosphate receptor, syntaxin7, LAMP-1 and LAMP-2 (Vieira et al., 2002). The final product, phagolysosomes, express LAMPs but have lost most of the earlier endosomal markers. In addition, the phagolysosomes possess a number of complementary degradative properties, including a very low $\mathrm{pH}$, hydrolytic enzymes for particle digestion, defensins and other bactericidal peptides, and the ability to generate toxic oxidative compounds (Amigorena and Savina, 2010; Rock et al., 2010).

Cellular material taken up by CD11b DCs rapidly ends up in fully matured phagolysosomes (Figures 3A-C; Savina et al., 2006, 2009; Reboulet et al., 2010; Peng and Elkon, 2011). Colocalization studies show an association of phagocytosed materials with LAMP-1+ organelles and pulse-chase experiments show the degradation of $>80 \%$ of the material in less than $20 \mathrm{~h}$ (Figures 3A,B). As a result, Ag are quickly processed and either

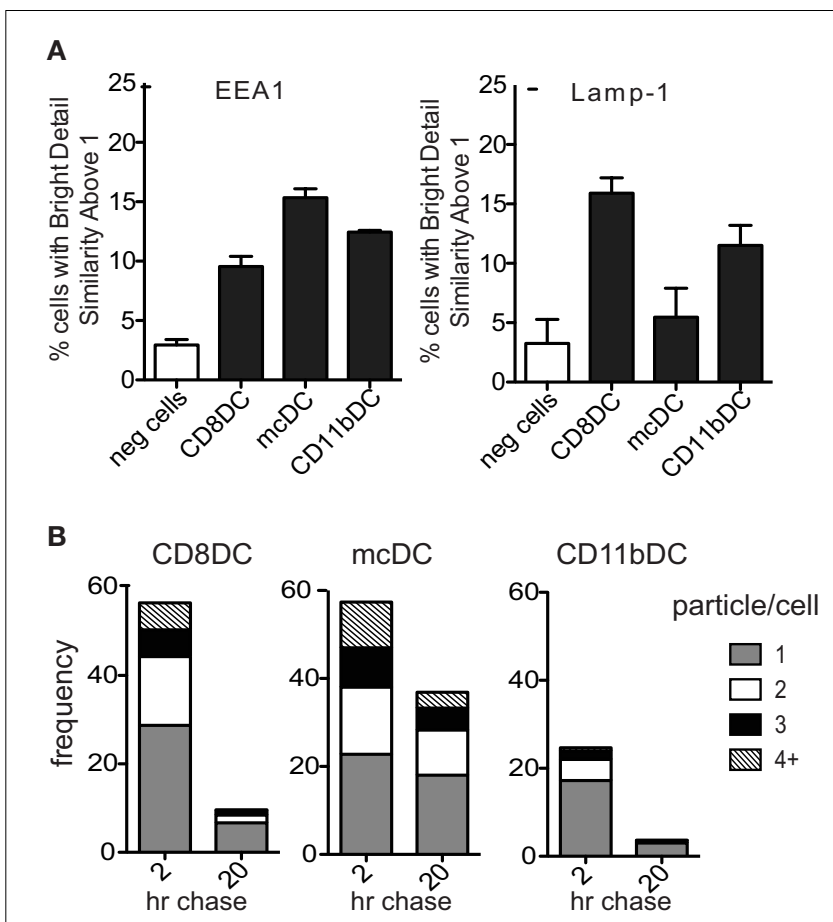

C

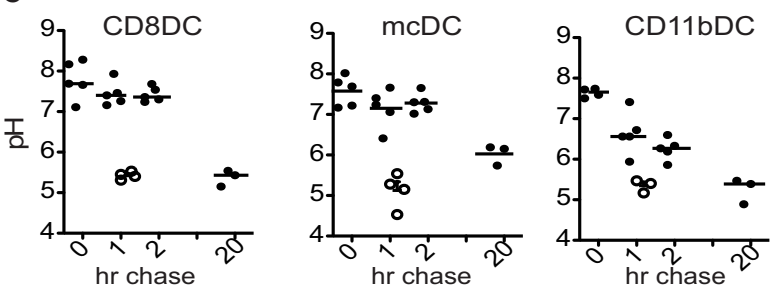

FIGURE 3 | Unique trafficking of phagocytosed material in cross-presenting DCs. (A) ImageStream analysis of the colocalization between internalized Violet labeled-irradiated cells and PE-labeled EEA-1 or LAMP-1 at $4 \mathrm{~h}$ ( $n>950$ events/group). Colocalization was based upon Bright Detail Similarity score between the two markers. Scores of 0-1 represent minimal colocalization. As the markers of interest become more colocalized the score increases to reflect this similarity. (B) ImageStream analysis of the frequency of CFSE-containing DCs and the number of CFSE+ particles per DC $2 \mathrm{~h}$ and $20 \mathrm{~h}$ after the removal of irradiated CFSE-labeled cells. Decreases in particle frequency and number/cell were attributed to acidification of the endosome and the subsequent CFSE-quenching. (C) Differences in lysosomal acidification rate between DC populations as determined by flow cytometric analysis of dual-labeled $\mathrm{pH}$-indicating beads. 
shuttled into MHC class II restricted pathways or simply degraded and disposed of. In contrast, cross-presenting DC subsets take up material from dying cells and hold these particles in immature endosomes for an extended period of time (Figures 3A-C). While CD8 $\alpha$ DCs have degraded most of the material after $20 \mathrm{~h}$, digestion is much slower than in CD11b DCs. Phagocytosed cellular particles in mcDCs are more colocalized with EEA-1 and less with LAMP- 1 after $4 \mathrm{~h}$ of co-incubation with irradiated cells, indicating slower endosomal maturation (Figure 3A). Moreover, pulse-chase studies showed the persistence of materials over a 20-h time span (Figure 3B; Reboulet et al., 2010). This persistence of Ag in the mcDCs has been shown to prolong the cross-presentation of specific cell-associated $\mathrm{Ag}$ and thereby increase T cell priming (Savina et al., 2006; Reboulet et al., 2010; Peng and Elkon, 2011).

As endosomal acidification causes the robust activation of lysosomal proteases and the subsequent destruction of Ag, acidification is considered to be poorly compatible with crosspresentation. Forced lysosomal acidification dramatically reduces cross-presentation while prevention of acidification has been shown to enhance cross-presentation (Savina et al., 2006; Amigorena and Savina, 2010; Reboulet et al., 2010). Though it was previously described that DCs have relative ineffective acidification of their lysosomes, the mechanism under pinning the sustained phagosome alkalinization was only recently unraveled. Studies by laboratory of Mellman and Amigorena indicate that this results from an incomplete assembly of V-ATPase in DC lysosomes and the Rab27-mediated recruitment of the NADPH NOX2. The NOX2-mediated generation of reactive oxygen species (ROS) in endocytic compartments causes the consumption of protons, followed by the active alkalinization of these compartments (Trombetta et al., 2003; Savina and Amigorena, 2007; Savina et al., 2009; Rock et al., 2010).

Acidification studies indicate that endosomes with cellassociated material in both CD $8 \alpha$ DCs and mcDCs maintain a similar high/neutral $\mathrm{pH}$ for several hours post uptake of cellassociated antigens, which correlates with Ag persistence. Compared to CD8 $\alpha$ DCs, mcDCs show decreased lysosomal acidification over a prolonged period of time, resulting in a less acidic endosomal compartment after $20 \mathrm{~h}$ (Figures 3B,C; Reboulet et al., 2010).

In both populations the treatment with diphenylene iodonium (DPI) - an inhibitor of flavin-containing enzymes such as NOX2 - accelerates lysosomal acidification, prevents Ag persistence, and rapidly decreases the cross-presenting capacity of both CD8 $\alpha$ DCs and mcDCs, emphasizing the importance of endosomal acidification in their cross-presentation (Reboulet et al., 2010).

The mechanisms that govern the prolonged Ag persistence in mcDC remain unclear as the biogenesis of phagolysosomes still involves many poorly understood processes. Transcriptome analysis of CD $\alpha$ DCs and mcDCs showed $\approx 20$-fold higher expression of Cybb (NOX2) in mcDCs. In addition, differential expression of various R- and Q-SNAREs (soluble $N$-ethyl maleimide sensitive-factor attachment protein receptors), sorting nexins, and $\mathrm{V}$-ATPases that have been suggested to play a role in vesicle transport and fusion are seen (Vieira et al., 2002; Cebrian et al., 2011). However, as most of these processes depend on active recruitment of these proteins to endosomal/lysosomal membranes, differences in expression levels might not be indicative of their degree of involvement. It is more likely that the nature of the phagocytosed particle - including size - and the receptors involved in their uptake dictate phagosome maturation (Peng and Elkon, 2011).

\section{PROCESSING AND MHC I LOADING}

As intact internalized Ag fill the cell, there are two proposed pathways by which they are cross-presented: the vacuolar and cytosolic pathways. The vacuolar pathway hypothesizes that cross-presented Ag are fully processed within the endosomes. The aminopeptidase IRAP facilitates the production of MHC class I-specific peptides that bind to the MHC molecule within the endosome. This pathway appears to be cathepsin S dependent and TAP independent (Shen et al., 2004; Chen and Jondal, 2008; Rock et al., 2010). In contrast, the cytosolic pathway requires minimally processed antigen to escape into the cytosol. Once in the cytosol, the Ag is processed by the proteasome, and generated peptides are shuttled into the lumen of the ER via sec61 or into phagosomes that have recruited ER components. The ER associated aminopeptidase ERAP actively clips the peptides to the proper length and TAP facilitates the loading into MHC class I (Rock et al., 2010).

Multiple studies indicate a dominant role for the cytosolic pathway in the processing of cell-associated Ag by cross-presenting DC subsets (Figure 4; Shen et al., 2004; Rock et al., 2010). Smaller particles, like those taken up by mcDCs and CD8 $\alpha$ DCs (Figure 2C), are more rapidly and efficiently exported to the cytosol, a process that would drive the cytosolic pathway of cross-presentation (Rodriguez et al., 1999). Also, lactacystin and brefeldin A, inhibitors of the proteasome and Golgi transport, respectively, completely inhibit the ability of both CD $8 \alpha$ DCs and mcDCs to activate Ag-specific $\mathrm{CD}^{+}{ }^{+} \mathrm{T}$ cells against cell-associated Ag (Figure 4). A recent report by Cebrian et al. (2011) implicates the SNARE protein Sec22b as an essential element of the cytosolic pathway. Depletion of Sec22b inhibits the recruitment of ER-resident proteins to the phagosome and phagolysosomal

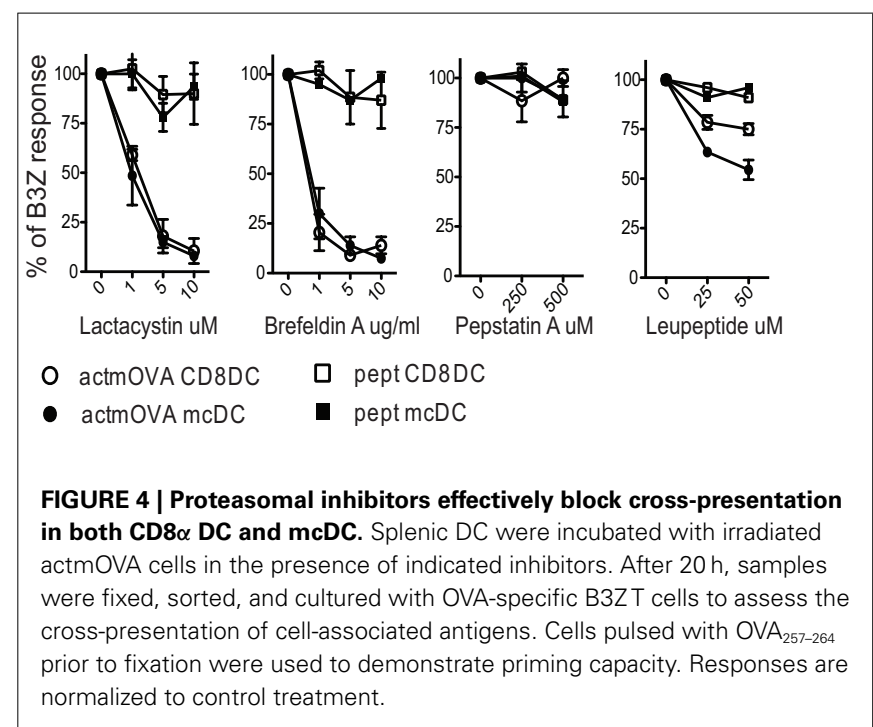


fusion was enhanced. As a result, antigens are rapidly degraded instead of being transported to the cytosol. These combined effects of Sec22b loss drastically reduce the cross-presentation of soluble and surface bound OVA as well as parasite and bacterial associated antigens. Interestingly, the presentation of both MHC class II and endogenous MHC class I restricted peptides is unaffected demonstrating significant separation between these processing pathways (Cebrian et al., 2011). Taken together, these data support the hypothesis that Ag must reach the cytosol, and eventually become associated with ER-derived proteins, to be cross-presented.

The maintenance of a more neutral $\mathrm{pH}$ correlates with delayed or reduced lysosomal protease activation. Cross-presenting DCs characteristically express lower levels of proteases and higher levels of protease inhibitors as compared to other APCs (LennonDumenil et al., 2002; Trombetta et al., 2003). Pepstatin A, an inhibitor of acid proteases involved in lysosomal maturation and acidification, has no effect on the DCs capacity to crosspresent. This demonstrates that protease mediated peptide production plays a minimal role in cross-presentation (Figure 4; Rock et al., 2010). Interestingly, leupeptin, an inhibitor of cysteine proteases essential for the vacuolar pathway, partially inhibits cross-presentation, but affected the mcDCs more than the CD8 $\alpha$ DC subset. This suggests that mcDCs may utilize the vacuolar pathway for the processing of cell-associated Ag more than other subsets. In support of this, removal of either ERAP or IRAP results in only a $50 \%$ reduction in cross-presentation, suggesting the utilization of both pathways by cross-presenting DCs (Firat et al., 2007; Blanchard et al., 2008; Saveanu et al., 2009; Rock et al., 2010).

\section{EFFECT OF AUTOCRINE CYTOKINE PRODUCTION}

The cytokines produced by DCs in the context of cellular death and clearance drastically influence Ag processing, presentation and, subsequently, the capacity of the DC to prime T cells against cell-associated Ag (Voll et al., 1997; Fadok et al., 1998; Janssen et al., 2006; Chung et al., 2007; Green et al., 2009). While the induction of anti-inflammatory cytokines - including IL-10 and TGF- $\beta$-upon uptake of apoptotic cells is relatively poor, various studies indicate that DC concurrently reduce their capacity to produce pro inflammatory cytokines (IL- $1 \alpha / \beta$, IL-6, IL-12, TNF $\alpha$; Stuart et al., 2002; Morelli et al., 2003). This altered cytokine production profile has been suggested to become entrenched in the APC and to affect subsequent spontaneous and induced cytokine production (Stuart et al., 2002; Morelli et al., 2003; Kim et al., 2004).

Upon exposure to apoptotic cells, CD11b DCs induce the antiinflammatory cytokines IL-10 and TGF- $\beta$ (Hennies et al., 2011). CD8 $\alpha$ DCs readily express the pro-inflammatory cytokines IL-12 and Type I IFN under inflammatory conditions (Hochrein et al., 2001; Heath et al., 2004; Naik et al., 2005), but demonstrate minimal induction of these and other cytokines, including IL-10 and TGF- $\beta$, in response to apoptotic cells (Morelli et al., 2003; Hennies et al., 2011; Janssen, unpublished). This is particularly interesting as CD $8 \alpha$ DCs produce TGF- $\beta$ during steady state (Yamazaki et al., 2008), a cytokine heavily implicated in the induction and maintenance of peripheral tolerance (Erwig and Henson, 2007; Green et al., 2009). In contrast, mcDCs express the pro-inflammatory cytokines IL-1 $\beta$ and type I IFN upon exposure to dying cells (Table 1; Hennies et al., 2011).

IL-10 and TGF- $\beta$ have potent immunosuppressive properties and promote the induction of tolerance. Both have been shown to reduce Ag presentation by regulating the transcription of the class I heavy chain, $\beta_{2} \mathrm{M}$, tapasin, TAP, and components of the proteasome (Geiser et al., 1993; Ma and Niederkorn, 1995; Koppelman et al., 1997; Nandan and Reiner, 1997; Salazar-Onfray et al., 1997; Zeidler et al., 1997; Strobl and Knapp, 1999; Francois et al., 2009). The pro-inflammatory cytokine IL-12 is a critical mediator of $\mathrm{CD}^{+} \mathrm{T}$ cell activation as it drives the necessary help of $\mathrm{CD}^{+}{ }^{+} \mathrm{T}$ cells toward a Th1 phenotype (Trinchieri, 2003; Trinchieri et al., 2003; Chang et al., 2004; Del Vecchio et al., 2007; Lee et al., 2007). In spite of this, IL-12 seems to have little autocrine effect on Ag processing by CD8 $\alpha$ DCs (Grohmann et al., 1999; Janssen, unpublished) and its induction has been suggested to require additional signals, including TLR engagement, CD40L, IL-4 or IFN- $\gamma$ (Hochrein et al., 2000; Hochrein et al., 2001; Reis e Sousa et al., 1997; Schulz et al., 2000). These additional stimuli - or their sequelae - positively affect the expression of the proteasomal subunits, TAP1 and TAP2, calnexin, calreticulin, tapasin, NOX2, and MHC class I.

Merocytic DCs produce pro-inflammatory cytokines in response to apoptotic cells without the apparent need for additional signals. While IL- $1 \beta$ is traditionally incorporated in maturation cocktails in the generation of human DCs, its does not significantly affect cross-presentation or cross-priming by mcDCs. mcDCs lacking IL-1RI or MyD88 display CD8 ${ }^{+} \mathrm{T}$ cell priming capacity similar to WT mcDCs (Janssen, unpublished). In contrast, type I IFN production by the mcDCs, and resulting autocrine signaling, is critical for this subset's enhanced cross-presentation and activation of $\mathrm{CD}^{+} \mathrm{T}$ cells against cell-associated Ag (Reboulet et al., 2010). Type I IFNs have been shown to affect the expression of various components of the Ag processing and loading machinery, including proteasome subunits, TAP, tapasin, calreticulin, NOX2, MHC, and various SNAREs (Cho et al., 2002; Tosello et al., 2009; Lattanzi et al., 2011). The importance of autocrine type I IFN production was illustrated in experiments where transfer of apoptotic cell-exposed mcDCs that lacked the type I IFN receptor (ifnar) showed significantly reduced priming of endogenous $\mathrm{CD} 8^{+} \mathrm{T}$ cells to cell-associated Ag compared to WT mcDCs. As CD8 $\alpha$ DCs do not produce type I IFN upon apoptotic cell uptake (Hennies et al., 2011), the presence or absence of the type I IFN $\alpha / \beta$ R on CD $8 \alpha$ DCs did not affect their priming capacity (Figure 5A). Further in vitro experiments showed that the reduction in priming correlated with reduced expression of the specific MHC-peptide complexes on the ifnar-mcDCs. No significant differences were observed in total MHC class I levels, suggesting that type I IFNs interfered relatively early in the process of $\mathrm{Ag}$ presentation.

Image stream analysis of WT and ifnar-/- CD8 $\alpha$ DCs and mcDCs exposed to dying cells in vitro indicated that type I IFN sensing did not affect the capacity for phagocytosis by either subset with regard to the frequency of phagocytosing cells, the number of particles per cell, or particle size (Figures 5B,C). However, pulse-chase studies indicated the absence of type I IFN 


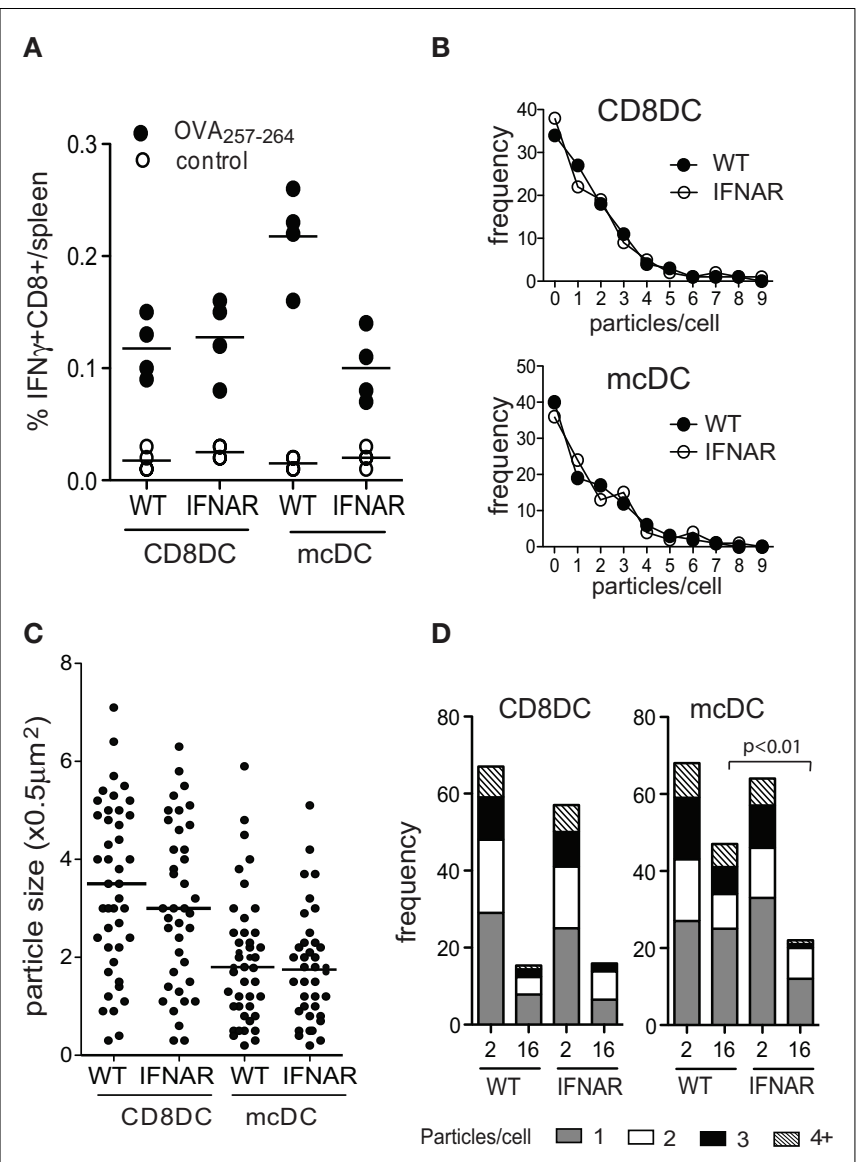

FIGURE 5 | Autocrine type I IFN signaling by mcDC affects CFSE loss on phagocytosed cellular particles suggesting changes in the lysosomal acidification rate. (A) $\mathrm{CD} 8 \alpha \mathrm{DCs}$ and $\mathrm{mcDCs}$ from indicated strains were exposed to irradiated actmOVA cells in vitro, purified and transferred into WT recipients. Seven days later the endogenous $C D 8^{+} T$ cell response was analyzed. (B,C) ImageStream analysis comparing the frequency and size of internalized CFSE-labeled particles in CD8 $\alpha$ DCs and mcDCs from WT and ifnar-/- mice. (D) Loss of delayed acidification in ifnar-/- mcDC as determined by ImageStream analysis using CFSE-labeled irradiated cells and a pulse-chase approach.

sensing accelerated CFSE loss, suggesting increased endosomal acidification, and significantly increased degradation of endosomal materials in mcDCs (Figure 5D). This is in line with recent findings of Lorenzi et al. (2011), who showed that pretreatment of CD8 $\alpha$ DCs with recombinant type I IFN, which is otherwise absent in these cultures, significantly increased Ag retention after engulfment of apoptotic cells. Increased retention correlated with decreased endosomal acidification and resulted in enhanced cross-presentation of cell-associated Ag (Lorenzi et al., 2011). Interestingly, two recent in vivo studies demonstrated a critical role for type I IFN sensing in DC in tumor rejection models. The authors showed that mice lacking ifnar in DC failed to reject highly immunogenic tumor cells and that CD8 $\alpha$ DCs from these mice displayed defects in antigen crosspresentation to $\mathrm{CD}^{+} \mathrm{T}$ cells (Diamond et al., 2011; Fuertes et al., 2011).
The concept of type I IFNs affecting endosomal $\mathrm{pH}$ and regulating Ag retention provides an intriguing concept that could explain why so many DC populations that fail to cross-present under steady state conditions are capable of doing so under inflammatory conditions associated with type I IFNs (Di Pucchio et al., 2008; Segura et al., 2009; Kamphorst et al., 2010; de Brito et al., 2011).

\section{OF MICE AND MEN}

While it is possible to perform extensive analysis on mouse DCs through the use of transgenic mice and the ability to remove specific organs, human DC studies are hampered by the limited availability of human lymphoid tissue and differences in DC surface markers. However, recent research indicates the existence of various human counterparts that - albeit phenotypically different - have functional similarities to mouse DCs. While the details on cross-presentation by human DCs are addressed elsewhere in this issue, it is noteworthy that cross-priming has been observed by human pDCs and the "CD8 $\alpha$ DC"-like DCs that expresses BDCA3, XCR1, DNGR1/Clec9A (Hoeffel et al., 2007; Dorner et al., 2009; Bachem et al., 2010; Henri et al., 2010; Crozat et al., 2011). Both cell types seem to have the capacity to actively internalize small particles of dead cell material. In addition, human DCs - like mouse DCs - require the regulation of phagosomal and endosomal $\mathrm{pH}$ for efficient cross-priming (Hoeffel et al., 2007; Amigorena and Savina, 2010). Whether these human DCs also encompass the counterpart of the human mcDCs is unclear. If human mcDCs would behave like mouse mcDCs, they would be associated with lymphoid tissue and very rare in blood. In this case it is interesting to note that most experiments using bloodderived or in vitro generated pDCs/BDCA3-DCs required inclusion of type I IFN inducing ligands to reveal their cross-priming ability.

\section{CONCLUDING REMARIKS}

Under steady state conditions, cross-presentation of cellassociated $\mathrm{Ag}$ is a continuous process that is imperative for the maintenance of peripheral tolerance. While great strides have been made in the elucidation of the mechanisms that govern crosspresentation and subsequent cross-priming, there are still many questions to be answered. Little is known about the proteins that orchestrate vesicle composition and trafficking or the signals involved in the recruitment of these proteins. It is likely that these processes are influenced by the composition and "state of decay" of the dying cells, the receptors involved in uptake, and the nature and maturation state of the DC. Moreover, in vivo, signals in trans provided by bystander cells can significantly affect intrinsic mechanisms of cross-presentation by DCs. Although elucidation of these processes may be a daunting task, increased mechanistic insight into these pathways will have tremendous therapeutic potential in the fields of autoimmune disease, transplantation, and cancer.

\section{ACKNOWLEDGMENTS}

The authors would like to thank Dr. C. Karp for critically reading the manuscript. This work is supported by NIH grant CA138617 (NCI) and AI079545 (NIAID) to Edith M. Janssen. 


\section{REFERENCES}

Albacker, L. A., Karisola, P., Chang, Y. J., Umetsu, S. E., Zhou, M., Akbari, O., Kobayashi, N., Baumgarth, N., Freeman, G. J., Umetsu, D. T., and DeKruyff, R. H. (2010). TIM4 , a receptor for phosphatidylserine, controls adaptive immunity by regulating the removal of antigenspecific T cells. J. Immunol. 185, 6839-6849.

Albert, M. L., Pearce, S. F., Francisco, L. M., Sauter, B., Roy, P., Silverstein, R. L., and Bhardwaj, N. (1998). Immature dendritic cells phagocytose apoptotic cells via alphavbeta5 and CD36, and cross-present antigens to cytotoxic T lymphocytes. $J$. Exp. Med. 188, 1359-1368.

Aliberti, J., Schulz, O., Pennington, D. J., Tsujimura, H., Reis e Sousa, C., Ozato, K., and Sher, A. (2003). Essential role for ICSBP in the in vivo development of murine CD8alpha+ dendritic cells. Blood 101, 305-310.

Allman, D., Dalod, M., Asselin-Paturel, C., Delale, T., Robbins, S. H., Trinchieri, G., Biron, C. A., Kastner, P., and Chan, S. (2006). Ikaros is required for plasmacytoid dendritic cell differentiation. Blood 108, 4025-4034.

Amigorena, S. (2002). Fc gamma receptors and cross-presentation in dendritic cells. J. Exp. Med. 195, F1-F3.

Amigorena, S., and Savina, A. (2010). Intracellular mechanisms of antigen cross presentation in dendritic cells. Curr. Opin. Immunol. 22, 109-117.

Anderson, K. L., Perkin, H., Surh, C. D., Venturini, S., Maki, R. A., and Torbett, B. E. (2000). Transcription factor PU.1 is necessary for development of thymic and myeloid progenitor-derived dendritic cells. J. Immunol. 164, 1855-1861.

Bachem, A., Guttler, S., Hartung, E., Ebstein, F., Schaefer, M., Tannert, A., Salama, A., Movassaghi, K., Opitz, C., Mages, H. W., Henn, V., Kloetzel, P. M., Gurka, S., and Kroczek, R. A. (2010). Superior antigen crosspresentation and XCR1 expression define human CD11c+ CD141+ cells as homologues of mouse CD8+ dendritic cells. J. Exp. Med. 207, 1273-1281.

Balasubramanian, K., Chandra, J., and Schroit, A. J. (1997). Immune clearance of phosphatidylserineexpressing cells by phagocytes. The role of beta2-glycoprotein I in macrophage recognition. J. Biol. Chem. 272, 31113-31117.

Bedoui, S., Prato, S., Mintern, J., Gebhardt, T., Zhan, Y., Lew, A. M., Heath, W. R., Villadangos, J. A., and
Segura, E. (2009a). Characterization of an immediate splenic precursor of CD8+ dendritic cells capable of inducing antiviral $\mathrm{T}$ cell responses. J. Immunol. 182, 4200-4207.

Bedoui, S., Whitney, P. G., Waithman, J., Eidsmo, L., Wakim, L., Caminschi, I., Allan, R. S., Wojtasiak, M., Shortman, K., Carbone, F. R., Brooks, A. G., and Heath, W. R. (2009b). Cross-presentation of viral and self antigens by skin-derived CD103+ dendritic cells. Nat. Immunol. 10, 488-495.

Belz, G. T., Behrens, G. M., Smith, C. M., Miller, J. F., Jones, C., Lejon, K., Fathman, C. G., Mueller, S. N., Shortman, K., Carbone, F. R., and Heath, W. R. (2002). The CD8alpha(+) dendritic cell is responsible for inducing peripheral self-tolerance to tissueassociated antigens. J. Exp. Med. 196, 1099-1104.

Belz, G. T., Shortman, K., Bevan, M. J., and Heath, W. R. (2005). CD8alpha+ dendritic cells selectively present MHC class I-restricted noncytolytic viral and intracellular bacterial antigens in vivo. $J$. Immunol. 175, 196-200.

Blanchard, N., Gonzalez, F., Schaeffer, M., Joncker, N. T., Cheng, T., Shastri, A. J., Robey, E. A., and Shastri, N. (2008). Immunodominant, protective response to the parasite Toxoplasma gondii requires antigen processing in the endoplasmic reticulum. Nat. Immunol. 9, 937-944.

Bonifaz, L., Bonnyay, D., Mahnke, K., Rivera, M., Nussenzweig, M. C., and Steinman, R. M. (2002). Efficient targeting of protein antigen to the dendritic cell receptor DEC-205 in the steady state leads to antigen presentation on major histocompatibility complex class I products and peripheral CD8 $+\mathrm{T}$ cell tolerance. $J$. Exp. Med. 196, 1627-1638.

Bonnefoy, F., Perruche, S., Couturier, M., Sedrati, A., Sun, Y., Tiberghien, P., Gaugler, B., and Saas, P. (2011). Plasmacytoid dendritic cells play a major role in apoptotic leukocyteinduced immune modulation. J. Immunol. 186, 5696-5705.

Borisenko, G. G., Iverson, S. L., Ahlberg, S., Kagan, V. E., and Fadeel, B. (2004). Milk fat globule epidermal growth factor 8 (MFG-E8) binds to oxidized phosphatidylserine: implications for macrophage clearance of apoptotic cells. Cell Death Differ. 11, 943-945.

Bratton, D. L., and Henson, P. M. (2008). Apoptotic cell recognition: will the real phosphatidylserine receptor(s) please stand up? Curr. Biol. 18, R76R79.
Burgdorf, S., Lukacs-Kornek, V., and Kurts, C. (2006). The mannose receptor mediates uptake of soluble but not of cell-associated antigen for cross-presentation. J. Immunol. 176 6770-6776.

Burgdorf, S., Scholz, C., Kautz, A., Tampe, R., and Kurts, C. (2008). Spatial and mechanistic separation of cross-presentation and endogenous antigen presentation. Nat. Immunol. 9, 558-566.

Burkly, L., Hession, C., Ogata, L., Reilly, C., Marconi, L. A., Olson, D., Tizard, R., Cate, R., and Lo, D. (1995). Expression of relB is required for the development of thymic medulla and dendritic cells. Nature 373, 531-536.

Cebrian, I., Visentin, G., Blanchard, N., Jouve, M., Bobard, A., Moita, C., Enninga, J., Moita, L. F., Amigorena, S., and Savina, A. (2011). Sec22b regulates phagosomal maturation and antigen crosspresentation by dendritic cells. Cell 147 1355-1368.

Chang, J., Cho, J. H., Lee, S. W., Choi, S. Y., Ha, S. J., and Sung, Y. C. (2004). IL-12 priming during in vitro antigenic stimulation changes properties of CD8 T cells and increases generation of effector and memory cells. $J$. Immunol. 172, 2818-2826.

Chen, L., and Jondal, M. (2008) Brefeldin A inhibits vesicular MHC class I processing in resting but not in CpG- and disruption-activated DC. Mol. Immunol. 46, 158-165.

Cho, H. J., Hayashi, T., Datta, S. K., Takabayashi, K., Van Uden, J. H., Horner, A., Corr, M., and Raz, E. (2002). IFN-alpha beta promote priming of antigen-specific CD8+ and CD4+ T lymphocytes by immunostimulatory DNA-based vaccines. $J$. Immunol. 168, 4907-4913.

Chung, E. Y., Liu, J., Homma, Y., Zhang, Y., Brendolan, A., Saggese, M., Han, J., Silverstein, R., Selleri, L., and Ma, X. (2007). Interleukin-10 expression in macrophages during phagocytosis of apoptotic cells is mediated by homeodomain proteins $\mathrm{Pbxl}$ and Prep-1. Immunity 27, 952-964.

Cisse, B., Caton, M. L., Lehner, M. Maeda, T., Scheu, S., Locksley, R., Holmberg, D., Zweier, C., den Hollander, N. S., Kant, S. G., Holter, W., Rauch, A., Zhuang, Y., and Reizis, B. (2008). Transcription factor E2-2 is an essential and specific regulator of plasmacytoid dendritic cell development. Cell 135, 37-48.

Crowley, M., Inaba, K., Witmer-Pack, M., and Steinman, R. M. (1989). The cell surface of mouse dendritic cells: FACS analyses of dendritic cells from different tissues including thymus. Cell. Immunol. 118, 108-125.

Crozat, K., Tamoutounour, S., Vu Manh, T. P., Fossum, E., Luche, H., Ardouin, L., Guilliams, M., Azukizawa, H., Bogen, B., Malissen, B., Henri, S., and Dalod, M. (2011). Cutting edge: expression of XCR1 defines mouse lymphoid-tissue resident and migratory dendritic cells of the CD8 $\{$ alpha $\}+$ type. J. Immunol. 187 , 4411-4415.

de Brito, C., Tomkowiak, M., Ghittoni, R., Caux, C., Leverrier, Y., and Marvel, J. (2011). CpG promotes crosspresentation of dead cell-associated antigens by pre-CD8alpha+ dendritic cells [corrected]. J. Immunol. 186, 1503-1511.

del Rio, M. L., Bernhardt, G., RodriguezBarbosa, J. I., and Forster, R. (2010) Development and functional specialization of $\mathrm{CD} 103+$ dendritic cells. Immunol. Rev. 234, 268-281.

Del Vecchio, M., Bajetta, E., Canova, S., Lotze, M. T., Wesa, A., Parmiani, G., and Anichini, A. (2007). Interleukin12: biological properties and clinical application. Clin. Cancer Res. 13, 4677-4685.

Delneste, Y., Magistrelli, G., Gauchat, J., Haeuw, J., Aubry, J., Nakamura, K., Kawakami-Honda, N., Goetsch, L., Sawamura, T., Bonnefoy, J., and Jeannin, P. (2002). Involvement of LOX-1 in dendritic cell-mediated antigen cross-presentation. Immunity 17, 353-362.

den Haan, J. M., and Bevan, M. J. (2002). Constitutive versus activationdependent cross-presentation of immune complexes by CD8(+) and CD8(-) dendritic cells in vivo. J. Exp. Med. 196, 817-827.

den Haan, J. M., Lehar, S. M., and Bevan, M. J. (2000). CD8(+) but not CD8(-) dendritic cells cross-prime cytotoxic T cells in vivo. J. Exp. Med. 192, 1685-1696.

Di Pucchio, T., Chatterjee, B., SmedSorensen, A., Clayton, S., Palazzo, A., Montes, M., Xue, Y., Mellman, I., Banchereau, J., and Connolly, J. E. (2008). Direct proteasomeindependent cross-presentation of viral antigen by plasmacytoid dendritic cells on major histocompatibility complex class I. Nat. Immunol. 9, 551-557.

Diamond, M. S., Kinder, M., Matsushita, H., Mashayekhi, M., Dunn, G. P., Archambault, J. M., Lee, H., Arthur, C. D., White, J. M., Kalinke, U., Murphy, K. M., and Schreiber, R. D. (2011). Type I interferon is selectively required by dendritic cells for immune rejection of tumors. J. Exp. Med. 208, 1989-2003. 
Dorner, B. G., Dorner, M. B., Zhou, X., Opitz, C., Mora, A., Guttler, S., Hutloff, A., Mages, H. W., Ranke, K., Schaefer, M., Jack, R. S., Henn, V., and Kroczek, R. A. (2009). Selective expression of the chemokine receptor XCR1 on cross-presenting dendritic cells determines cooperation with CD8+ T cells. Immunity 31, 823-833.

Edwards, A. D., Diebold, S. S., Slack, E. M., Tomizawa, H., Hemmi, H., Kaisho, T., Akira, S., and Reis e Sousa, C. (2003). Toll-like receptor expression in murine DC subsets: lack of TLR7 expression by CD8 alpha+ DC correlates with unresponsiveness to imidazoquinolines. Eur. J. Immunol. 33, 827-833.

Ehst, B. D., Ingulli, E., and Jenkins, M. K. (2003). Development of a novel transgenic mouse for the study of interactions between CD4 and CD8 T cells during graft rejection. Am. J. Transplant. 3, 1355-1362.

El-Sukkari, D., Wilson, N. S., Hakansson, K., Steptoe, R. J., Grubb, A., Shortman, K., and Villadangos, J. A. (2003). The protease inhibitor cystatin $\mathrm{C}$ is differentially expressed among dendritic cell populations, but does not control antigen presentation. J. Immunol. 171, 5003-5011.

Elward, K., and Gasque, P. (2003). "Eat me" and "don't eat me" signals govern the innate immune response and tissue repair in the CNS: emphasis on the critical role of the complement system. Mol. Immunol. 40, 85-94.

Erwig, L. P., and Henson, P. M. (2007). Immunological consequences of apoptotic cell phagocytosis. Am. J. Pathol. 171, 2-8.

Erwig, L. P., and Henson, P. M. (2008). Clearance of apoptotic cells by phagocytes. Cell Death Differ. 15, 243-250.

Fadok, V. A., Bratton, D. L., Konowal, A., Freed, P. W., Westcott, J. Y., and Henson, P. M. (1998). Macrophages that have ingested apoptotic cells in vitro inhibit proinflammatory cytokine production through autocrine/paracrine mechanisms involving TGF-beta, PGE2, and PAF. J. Clin. Invest. 101, 890-898.

Ferguson, T. A., Choi, J., and Green, D. R. (2011). Armed response: how dying cells influence T-cell functions. Immunol. Rev. 241, 77-88.

Ferguson, T. A., Herndon, J., Elzey, B., Griffith, T. S., Schoenberger, S., and Green, D. R. (2002). Uptake of apoptotic antigen-coupled cells by lymphoid dendritic cells and cross-priming of $\mathrm{CD} 8(+) \mathrm{T}$ cells produce active immune unre- sponsiveness. J. Immunol. 168, 5589-5595.

Fifis, T., Gamvrellis, A., Crimeen-Irwin, B., Pietersz, G. A., Li, J., Mottram, P. L., McKenzie, I. F., and Plebanski, M. (2004). Size-dependent immunogenicity: therapeutic and protective properties of nano-vaccines against tumors. J. Immunol. 173, 3148-3154.

Firat, E., Saveanu, L., Aichele, P., Staeheli, P., Huai, J., Gaedicke, S., Nil, A., Besin, G., Kanzler, B., van Endert, P., and Niedermann, G. (2007). The role of endoplasmic reticulumassociated aminopeptidase 1 in immunity to infection and in cross-presentation. J. Immunol. 178, 2241-2248.

Flinsenberg, T. W., Compeer, E. B., Boelens, J. J., and Boes, M. (2011). Antigen cross-presentation: extending recent laboratory findings to therapeutic intervention. Clin. Exp. Immunol. 165, 8-18.

Francois, M., Romieu-Mourez, R., Stock-Martineau, S., Boivin, M. N., Bramson, J. L., and Galipeau, J. (2009). Mesenchymal stromal cells cross-present soluble exogenous antigens as part of their antigen-presenting cell properties. Blood 114, 2632-2638.

Fuertes, M. B., Kacha, A. K., Kline, J., Woo, S. R., Kranz, D. M., Murphy, K. M., and Gajewski, T. F. (2011). Host type I IFN signals are required for antitumor $\mathrm{CD} 8+\mathrm{T}$ cell responses through $\mathrm{CD} 8\{$ alpha $\}+$ dendritic cells. J. Exp. Med. 208, 2005-2016.

Geiser, A. G., Letterio, J. J., Kulkarni, A. B., Karlsson, S., Roberts, A. B., and Sporn, M. B. (1993). Transforming growth factor beta 1 (TGF-beta 1) controls expression of major histocompatibility genes in the postnatal mouse: aberrant histocompatibility antigen expression in the pathogenesis of the TGF-beta 1 null mouse phenotype. Proc. Natl. Acad. Sci. U.S.A. 90, 9944-9948.

Green, D. R., Ferguson, T., Zitvogel, L., and Kroemer, G. (2009). Immunogenic and tolerogenic cell death. Nat. Rev. Immunol. 9, 353-363.

Griffith, T. S., Kazama, H., VanOosten, R. L., Earle, J. K. Jr., Herndon, J. M., Green, D. R., and Ferguson, T. A. (2007). Apoptotic cells induce tolerance by generating helpless CD8+ $\mathrm{T}$ cells that produce TRAIL. J. Immunol. 178, 2679-2687. Grohmann, U., Bianchi, R., Belladonna, M. L., Vacca, C., Silla, S., Ayroldi, E., Fioretti, M. C., and Puccetti, P. (1999). IL-12 acts selectively on CD8 alpha-dendritic cells to enhance presentation of a tumor peptide in vivo. J. Immunol. 163, 3100-3105. Guerriero, A., Langmuir, P. B., Spain L. M., and Scott, E. W. (2000) PU.1 is required for myeloid-derived but not lymphoid-derived dendritic cells. Blood 95, 879-885.

Hacker, C., Kirsch, R. D., Ju, X. S. Hieronymus, T., Gust, T. C., Kuhl, C., Jorgas, T., Kurz, S. M., RoseJohn, S., Yokota, Y., and Zenke, M. (2003). Transcriptional profiling identifies Id 2 function in dendritic cell development. Nat. Immunol. 4, 380-386.

Hanayama, R., Tanaka, M., Miyasaka, K., Aozasa, K., Koike, M., Uchiyama, Y., and Nagata, S. (2004). Autoimmune disease and impaired uptake of apoptotic cells in MFG-E8-deficient mice. Science 304, 1147-1150.

Hashimoto, D., Miller, J., and Merad, M. (2011). Dendritic cell and macrophage heterogeneity in vivo. Immunity 35, 323-335.

Hawiger, D., Inaba, K., Dorsett, Y., Guo, M., Mahnke, K., Rivera, M., Ravetch, J. V., Steinman, R. M., and Nussenzweig, M. C. (2001). Dendritic cells induce peripheral $\mathrm{T}$ cell unresponsiveness under steady state conditions in vivo. J. Exp. Med. 194 769-779.

Heath, W. R., Belz, G. T., Behrens, G. M. Smith, C. M., Forehan, S. P., Parish, I. A., Davey, G. M., Wilson, N. S., Carbone, F. R., and Villadangos, J. A. (2004). Cross-presentation, dendritic cell subsets, and the generation of immunity to cellular antigens. Immunol. Rev. 199, 9-26.

Hemmi, H., Idoyaga, J., Suda, K., Suda, N., Kennedy, K., Noda, M., Aderem, A., and Steinman, R. M. (2009). A new triggering receptor expressed on myeloid cells (Trem) family member, Trem-like 4, binds to dead cells and is a DNAX activation protein 12linked marker for subsets of mouse macrophages and dendritic cells. J. Immunol. 182, 1278-1286.

Hennies, C. M., Reboulet, R. A., Garcia, Z., Nierkens, S., Wolkers, M. C. and Janssen, E. M. (2011). Selective expansion of merocytic dendritic cells and CD8DCs confers antitumour effect of Fms-like tyrosine kinase 3-ligand treatment in vivo. Clin. Exp. Immunol. 163, 381-391.

Henri, S., Poulin, L. F., Tamoutounour, S., Ardouin, L., Guilliams, M., de Bovis, B., Devilard, E., Viret, C. Azukizawa, H., Kissenpfennig, A., and Malissen, B. (2010). CD207+ CD103+ dermal dendritic cells cross-present keratinocyte-derived antigens irrespective of the presence of Langerhans cells. J. Exp. Med. 207, 189-206.
Hildner, K., Edelson, B. T., Purtha, W. E., Diamond, M., Matsushita, H., Kohyama, M., Calderon, B., Schraml, B. U., Unanue, E. R., Diamond, M. S., Schreiber, R. D., Murphy, T. L., and Murphy, K. M. (2008). Batf3 deficiency reveals a critical role for CD8alpha+ dendritic cells in cytotoxic T cell immunity. Science 322 , 1097-1100.

Hochrein, H., O'Keeffe, M., Luft, T. Vandenabeele, S., Grumont, R. J., Maraskovsky, E., and Shortman, K. (2000). Interleukin (IL)-4 is a major regulatory cytokine governing bioactive IL-12 production by mouse and human dendritic cells. $J$ Exp. Med. 192, 823-833.

Hochrein, H., Shortman, K., Vremec, D., Scott, B., Hertzog, P., and O'Keeffe, M. (2001). Differential production of IL-12, IFN-alpha, and IFNgamma by mouse dendritic cell subsets. J. Immunol. 166, 5448-5455.

Hoeffel, G., Ripoche, A. C., Matheoud, D., Nascimbeni, M., Escriou, N., Lebon, P., Heshmati, F., Guillet, J. G., Gannage, M., Caillat-Zucman, S., Casartelli, N., Schwartz, O., De la Salle, H., Hanau, D., Hosmalin, A., and Maranon, C. (2007). Antigen crosspresentation by human plasmacytoid dendritic cells. Immunity 27, 481-492.

Honda, K., Mizutani, T., and Taniguchi, T. (2004). Negative regulation of IFN-alpha/beta signaling by IFN regulatory factor 2 for homeostatic development of dendritic cells. Proc. Natl. Acad. Sci. U.S.A. 101, 2416-2421.

Ichikawa, E., Hida, S., Omatsu, Y., Shimoyama, S., Takahara, K., Miyagawa, S., Inaba, K., and Taki, S. (2004). Defective development of splenic and epidermal CD4+ dendritic cells in mice deficient for IFN regulatory factor-2. Proc. Natl. Acad. Sci. U.S.A. 101, 3909-3914.

Ishimoto, Y., Ohashi, K., Mizuno, K., and Nakano, T. (2000). Promotion of the uptake of PS liposomes and apoptotic cells by a product of growth arrest-specific gene, gas6. J. Biochem. 127, 411-417.

Iyoda, T., Shimoyama, S., Liu, K., Omatsu, Y., Akiyama, Y., Maeda, Y., Takahara, K., Steinman, R. M., and Inaba, K. (2002). The CD8+ dendritic cell subset selectively endocytoses dying cells in culture and in vivo. J. Exp. Med. 195, 1289-1302. Janssen, E., Tabeta, K., Barnes, M. J., Rutschmann, S., McBride, S., Bahjat, K. S., Schoenberger, S. P., Theofilopoulos, A. N., Beutler, B., and Hoebe, K. (2006). Efficient T cell activation via a Toll-Interleukin 
1 Receptor-independent pathway. Immunity 24, 787-799.

Janssen, E. M., Droin, N. M., Lemmens, E. E., Pinkoski, M. J., Bensinger, S. J., Ehst, B. D., Griffith, T. S., Green, D. R., and Schoenberger, S. P. (2005). CD4+ T-cell help controls CD8+ T-cell memory via TRAILmediated activation-induced cell death. Nature 434, 88-93.

Janssen, E. M., Lemmens, E. E., Wolfe, T., Christen, U., von Herrath, M. G., and Schoenberger, S. P. (2003). CD4+ $\mathrm{T}$ cells are required for secondary expansion and memory in CD8+ T lymphocytes. Nature 421, 852-856.

Kalergis, A. M., and Ravetch, J.V. (2002). Inducing tumor immunity through the selective engagement of activating Fcgamma receptors on dendritic cells. J. Exp. Med. 195, 1653-1659.

Kamphorst, A. O., Guermonprez, P., Dudziak, D., and Nussenzweig, M. C. (2010). Route of antigen uptake differentially impacts presentation by dendritic cells and activated monocytes. J. Immunol. 185, 3426-3435.

Karttunen, J., Sanderson, S., and Shastri, N. (1992). Detection of rare antigenpresenting cells by the lacZ T-cell activation assay suggests an expression cloning strategy for T-cell antigens. Proc. Natl. Acad. Sci. U.S.A. 89, 6020-6024.

Katz, J. D., Ondr, J. K., Opoka, R. J., Garcia, Z., and Janssen, E. M. (2010). Cutting edge: merocytic dendritic cells break $\mathrm{T}$ cell tolerance to beta cell antigens in nonobese diabetic mouse diabetes. J. Immunol. 185, 1999-2003.

Kim, S., Elkon, K. B., and Ma, X. (2004). Transcriptional suppression of interleukin-12 gene expression following phagocytosis of apoptotic cells. Immunity 21, 643-653.

Kobayashi, N., Karisola, P., Pena-Cruz, V., Dorfman, D. M., Jinushi, M., Umetsu, S. E., Butte, M. J., Nagumo, H., Chernova, I., Zhu, B., Sharpe, A. H., Ito, S., Dranoff, G., Kaplan, G. G., Casasnovas, J. M., Umetsu, D. T., Dekruyff, R. H., and Freeman, G. J. (2007). TIM-1 and TIM-4 glycoproteins bind phosphatidylserine and mediate uptake of apoptotic cells. Immunity 27, 927-940.

Koppelman, B., Neefjes, J. J., de Vries, J. E., and de Waal Malefyt, R. (1997). Interleukin-10 downregulates MHC class II alphabeta peptide complexes at the plasma membrane of monocytes by affecting arrival and recycling. Immunity 7, 861-871.

Kraal, G., Breel, M., Janse, M., and Bruin, G. (1986). Langerhans' cells, veiled cells, and interdigitating cells in the mouse recognized by a monoclonal antibody. J. Exp. Med. 163, 981-997.

Krysko, D. V., and Vandenabeele, P. (2008). From regulation of dying cell engulfment to development of anticancer therapy. Cell Death Differ. 15, 29-38.

Kurts, C., Heath, W. R., Carbone, F. R., Allison, J., Miller, J. F., and Kosaka, H. (1996). Constitutive class I-restricted exogenous presentation of self antigens in vivo. J. Exp. Med. 184, 923-930.

Kurts, C., Heath, W. R., Kosaka, H., Miller, J. F., and Carbone, F. R. (1998). The peripheral deletion of autoreactive $\mathrm{CD} 8+\mathrm{T}$ cells induced by cross-presentation of self-antigens involves signaling through CD95 (Fas, Apo-1). J. Exp. Med. 188, 415-420.

Kushwah, R., and Hu, J. (2011). Complexity of dendritic cell subsets and their function in the host immune system. Immunology 133, 409-419.

Lahoud, M. H., Proietto, A. I., Ahmet, F., Kitsoulis, S., Eidsmo, L., Wu, L., Sathe, P., Pietersz, S., Chang, H. W., Walker, I. D., Maraskovsky, E., Braley, H., Lew, A. M., Wright, M. D., Heath, W. R., Shortman, K., and Caminschi, I. (2009). The C-type lectin Clec12A present on mouse and human dendritic cells can serve as a target for antigen delivery and enhancement of antibody responses. J. Immunol. 182, 7587-7594.

Lahoud, M. H., Proietto, A. I., Gartlan, K. H., Kitsoulis, S., Curtis, J., Wettenhall, J., Sofi, M., Daunt, C., O'Keeffe, M., Caminschi, I., Satterley, K., Rizzitelli, A., Schnorrer, P., Hinohara, A., Yamaguchi, Y., Wu, L., Smyth, G., Handman, E., Shortman, K., and Wright, M. D. (2006). Signal regulatory protein molecules are differentially expressed by $\mathrm{CD} 8^{-}$ dendritic cells. J. Immunol. 177, 372-382.

Lattanzi, L., Rozera, C., Marescotti, D., D'Agostino, G., Santodonato, L., Cellini, S., Belardelli, F., Gavioli, R., and Ferrantini, M. (2011). IFN-alpha boosts epitope crosspresentation by dendritic cells via modulation of proteasome activity. Immunobiology 216, 537-547.

Lee, J. B., Lee, K. A., and Chang, J. (2007). Phenotypic changes induced by IL-12 priming regulate effector and memory CD8 $\mathrm{T}$ cell differentiation. Int. Immunol. 19, 1039-1048.

Lennon-Dumenil, A. M., Bakker, A. H., Maehr, R., Fiebiger, E., Overkleeft, H. S., Rosemblatt, M., Ploegh, H. L., and Lagaudriere-Gesbert, C. (2002). Analysis of protease activity in live antigen-presenting cells shows regulation of the phagosomal proteolytic contents during dendritic cell activation. J. Exp. Med. 196, 529-540.

Liu, K., and Nussenzweig, M. C. (2010). Origin and development of dendritic cells. Immunol. Rev. 234, 45-54.

Liu, K., Victora, G. D., Schwickert, T. A., Guermonprez, P., Meredith, M. M., Yao, K., Chu, F. F., Randolph, G. J., Rudensky, A. Y., and Nussenzweig, M. (2009). In vivo analysis of dendritic cell development and homeostasis. Science 324, 392-397.

Lorenzi, S., Mattei, F., Sistigu, A., Bracci, L., Spadaro, F., Sanchez, M., Spada, M., Belardelli, F., Gabriele, L., and Schiavoni, G. (2011). Type I IFNs control antigen retention and survival of CD8alpha $(+)$ dendritic cells after uptake of tumor apoptotic cells leading to cross-priming. $J$. Immunol. 186, 5142-5150.

Ma, D., and Niederkorn, J. Y. (1995). Transforming growth factor-beta down-regulates major histocompatibility complex class I antigen expression and increases the susceptibility of uveal melanoma cells to natural killer cell-mediated cytolysis. Immunology 86, 263-269.

Maldonado-Lopez, R., and Moser, M. (2001). Dendritic cell subsets and the regulation of Th1/Th2 responses. Semin. Immunol. 13, 275-282.

McLellan, A. D., Kapp, M., Eggert, A., Linden, C., Bommhardt, U., Brocker, E. B., Kammerer, U., and Kampgen, E. (2002). Anatomic location and T-cell stimulatory functions of mouse dendritic cell subsets defined by CD4 and CD8 expression. Blood 99, 2084-2093.

Morelli, A. E., Larregina, A. T., Shufesky, W. J., Zahorchak, A. F., Logar, A. J., Papworth, G. D., Wang, Z., Watkins, S. C., Falo, L. D. Jr., and Thomson, A. W. (2003). Internalization of circulating apoptotic cells by splenic marginal zone dendritic cells: dependence on complement receptors and effect on cytokine production. Blood 101, 611-620.

Naik, S. H., Proietto, A. I., Wilson, N. S., Dakic, A., Schnorrer, P., Fuchsberger, M., Lahoud, M. H., O'Keeffe, M., Shao, Q. X., Chen, W. F., Villadangos, J. A., Shortman, K., and Wu, L. (2005). Cutting edge: generation of splenic CD8+ and CD8 ${ }^{-}$ dendritic cell equivalents in Fmslike tyrosine kinase 3 ligand bone marrow cultures. J. Immunol. 174, 6592-6597.

Nakayama, M., Akiba, H., Takeda, K., Kojima, Y., Hashiguchi, M., Azuma,
M., Yagita, H., and Okumura, K. (2009). Tim-3 mediates phagocytosis of apoptotic cells and crosspresentation. Blood 113, 3821-3830.

Nandan, D., and Reiner, N. E. (1997). TGF-beta attenuates the class II transactivator and reveals an accessory pathway of IFN-gamma action. J. Immunol. 158, 1095-1101.

Oka, K., Sawamura, T., Kikuta, K., Itokawa, S., Kume, N., Kita, T., and Masaki, T. (1998). Lectinlike oxidized low-density lipoprotein receptor 1 mediates phagocytosis of aged/apoptotic cells in endothelial cells. Proc. Natl. Acad. Sci. U.S.A. 95, 9535-9540.

Peng, Y., and Elkon, K. B. (2011). Autoimmunity in MFG-E8-deficient mice is associated with altered trafficking and enhanced crosspresentation of apoptotic cell antigens. J. Clin. Invest. 121, 2221-2241.

Platt, N., Suzuki, H., Kodama, T., and Gordon, S. (2000). Apoptotic thymocyte clearance in scavenger receptor class A-deficient mice is apparently normal. J. Immunol. 164, 4861-4867.

Pooley, J. L., Heath, W. R., and Shortman, K. (2001). Cutting edge: intravenous soluble antigen is presented to $\mathrm{CD} 4 \mathrm{~T}$ cells by $\mathrm{CD} 8-$ dendritic cells, but cross-presented to CD8 $\mathrm{T}$ cells by $\mathrm{CD} 8+$ dendritic cells. $J$. Immunol. 166, 5327-5330.

Poon, I. K., Hulett, M. D., and Parish, C. R. (2010). Molecular mechanisms of late apoptotic/necrotic cell clearance. Cell Death Differ. 17, 381-397.

Pribila, J. T., Itano, A. A., Mueller, K. L., and Shimizu, Y. (2004). The alpha 1 beta 1 and alpha $\mathrm{E}$ beta 7 integrins define a subset of dendritic cells in peripheral lymph nodes with unique adhesive and antigen uptake properties. J. Immunol. 172, 282-291.

Pulendran, B., Lingappa, J., Kennedy, M. K., Smith, J., Teepe, M., Rudensky, A., Maliszewski, C. R., and Maraskovsky, E. (1997). Developmental pathways of dendritic cells in vivo: distinct function, phenotype, and localization of dendritic cell subsets in FLT3 ligand-treated mice. J. Immunol. 159, 2222-2231.

Qiu, C. H., Miyake, Y., Kaise, H., Kitamura, H., Ohara, O., and Tanaka, M. (2009). Novel subset of CD8\{alpha\}+ dendritic cells localized in the marginal zone is responsible for tolerance to cellassociated antigens. J. Immunol. 182, 4127-4136.

Reboulet, R. A., Hennies, C. M., Garcia, Z., Nierkens, S., and Janssen, E. M. (2010). Prolonged antigen storage endows merocytic dendritic cells 
with enhanced capacity to prime anti-tumor responses in tumorbearing mice. J. Immunol. 185, 3337-3347.

Regnault, A., Lankar, D., Lacabanne, V., Rodriguez, A., Thery, C., Rescigno, M., Saito, T., Verbeek, S., Bonnerot, C., Ricciardi-Castagnoli, P., and Amigorena, S. (1999). Fcgamma receptor-mediated induction of dendritic cell maturation and major histocompatibility complex class Irestricted antigen presentation after immune complex internalization. J. Exp. Med. 189, 371-380.

Reis e Sousa, C., Hieny, S., SchartonKersten, T., Jankovic, D., Charest, H., Germain, R. N., and Sher, A. (1997). In vivo microbial stimulation induces rapid CD40 ligandindependent production of interleukin 12 by dendritic cells and their redistribution to T cell areas. J. Exp. Med. 186, 1819-1829.

Rejman, J., Oberle, V., Zuhorn, I. S., and Hoekstra, D. (2004). Size-dependent internalization of particles via the pathways of clathrin- and caveolaemediated endocytosis. Biochem. J. 377, 159-169.

Robbins, S. H., Walzer, T., Dembele, D., Thibault, C., Defays, A., Bessou, G., Xu, H., Vivier, E., Sellars, M., Pierre, P., Sharp, F. R., Chan, S., Kastner, P., and Dalod, M. (2008). Novel insights into the relationships between dendritic cell subsets in human and mouse revealed by genome-wide expression profiling. Genome Biol. 9, R17.

Rock, K. L., Farfan-Arribas, D. J., and Shen, L. (2010). Proteases in MHC class I presentation and crosspresentation. J. Immunol. 184, 9-15.

Rodriguez, A., Regnault, A., Kleijmeer, M., Ricciardi-Castagnoli, P., and Amigorena, S. (1999). Selective transport of internalized antigens to the cytosol for MHC class I presentation in dendritic cells. Nat. Cell Biol. 1, 362-368.

Ronchetti, A., Rovere, P., Iezzi, G., Galati, G., Heltai, S., Protti, M. P., Garancini, M. P., Manfredi, A. A., Rugarli, C., and Bellone, M. (1999). Immunogenicity of apoptotic cells in vivo: role of antigen load, antigenpresenting cells, and cytokines. J. Immunol. 163, 130-136.

Salazar-Onfray, F., Charo, J., Petersson, M., Freland, S., Noffz, G., Qin, Z., Blankenstein, T., Ljunggren, H. G., and Kiessling, R. (1997). Downregulation of the expression and function of the transporter associated with antigen processing in murine tumor cell lines expressing IL-10. J. Immunol. 159, 3195-3202.
Sallusto, F., Cella, M., Danieli, C., and Lanzavecchia, A. (1995). Dendritic cells use macropinocytosis and the mannose receptor to concentrate macromolecules in the major histocompatibility complex class II compartment: downregulation by cytokines and bacterial products. $J$. Exp. Med. 182, 389-400.

Sancho, D., Joffre, O. P., Keller, A. M., Rogers, N. C., Martinez, D., Hernanz-Falcon, P., Rosewell, I., and Reis e Sousa, C. (2009). Identification of a dendritic cell receptor that couples sensing of necrosis to immunity. Nature 458, 899-903.

Sancho, D., Mourao-Sa, D., Joffre, O. P., Schulz, O., Rogers, N. C., Pennington, D. J., Carlyle, J. R., and Reis e Sousa, C. (2008). Tumor therapy in mice via antigen targeting to a novel, DC-restricted C-type lectin. J. Clin. Invest. 118, 2098-2110.

Sathe, P., and Shortman, K. (2008). The steady-state development of splenic dendritic cells. Mucosal Immunol. 1, 425-431.

Saveanu, L., Carroll, O., Weimershaus, M., Guermonprez, P., Firat, E., Lindo, V., Greer, F., Davoust, J., Kratzer, R., Keller, S. R., Niedermann, G., and van Endert, P. (2009). IRAP identifies an endosomal compartment required for MHC class I cross-presentation. Science 325, 213-217.

Savina, A., and Amigorena, S. (2007). Phagocytosis and antigen presentation in dendritic cells. Immunol. Rev. 219, 143-156.

Savina, A., Jancic, C., Hugues, S., Guermonprez, P., Vargas, P., Moura, I. C., Lennon-Dumenil, A. M., Seabra, M. C., Raposo, G., and Amigorena, S. (2006). NOX2 controls phagosomal $\mathrm{pH}$ to regulate antigen processing during crosspresentation by dendritic cells. Cell 126, 205-218.

Savina, A., Peres, A., Cebrian, I., Carmo, N., Moita, C., Hacohen, N., Moita, L. F., and Amigorena, S. (2009). The small GTPase Rac2 controls phagosomal alkalinization and antigen crosspresentation selectively in CD8(+) dendritic cells. Immunity 30, 544-555.

Scheinecker, C., McHugh, R., Shevach, E. M., and Germain, R. N. (2002). Constitutive presentation of a natural tissue autoantigen exclusively by dendritic cells in the draining lymph node. J. Exp. Med. 196, 1079-1090.

Schiavoni, G., Mattei, F., Sestili, P., Borghi, P., Venditti, M., Morse, H. C. III, Belardelli, F., and Gabriele, L. (2002). ICSBP is essential for the development of mouse type I interferon-producing cells and for the generation and activation of CD8alpha(+) dendritic cells. J. Exp. Med. 196, 1415-1425.

Schnorrer, P., Behrens, G. M., Wilson, N. S., Pooley, J. L., Smith, C. M., ElSukkari, D., Davey, G., Kupresanin, F., Li, M., Maraskovsky, E., Belz, G. T., Carbone, F. R., Shortman, K. Heath, W. R., and Villadangos, J. A. (2006). The dominant role of CD8+ dendritic cells in cross-presentation is not dictated by antigen capture. Proc. Natl. Acad. Sci. U.S.A. 103, 10729-10734.

Schotte, R., Nagasawa, M., Weijer, K., Spits, H., and Blom, B. (2004). The ETS transcription factor Spi-B is required for human plasmacytoid dendritic cell development. J. Exp. Med. 200, 1503-1509.

Schulz, O., Edwards, A. D., Schito, M., Aliberti, J., Manickasingham, S., Sher, A., and Reis e Sousa, C. (2000). CD40 triggering of heterodimeric IL-12 p70 production by dendritic cells in vivo requires a microbial priming signal. Immunity 13, 453-462.

Schulz, O., and Reis e Sousa, C. (2002). Cross-presentation of cellassociated antigens by CD8alpha+ dendritic cells is attributable to their ability to internalize dead cells. Immunology 107, 183-189.

Scott, R. S., McMahon, E. J., Pop, S. M., Reap, E. A., Caricchio, R., Cohen, P. L., Earp, H. S., and Matsushima, G. K. (2001). Phagocytosis and clearance of apoptotic cells is mediated by MER. Nature 411, 207-211.

Segura, E., Albiston, A. L., Wicks, I. P., Chai, S. Y., and Villadangos, J. A (2009). Different cross-presentation pathways in steady-state and inflammatory dendritic cells. Proc. Natl. Acad. Sci. U.S.A. 106, 20377-20381.

Shen, L., Sigal, L. J., Boes, M., and Rock, K. L. (2004). Important role of cathepsin $\mathrm{S}$ in generating peptides for TAP-independent MHC class I crosspresentation in vivo. Immunity 21, 155-165.

Shortman, K., and Heath, W. R. (2010) The CD8+ dendritic cell subset. Immunol. Rev. 234, 18-31.

Shortman, K., and Liu, Y. J. (2002). Mouse and human dendritic cell subtypes. Nat. Rev. Immunol. 2, 151-161.

Shortman, K., and Naik, S. H. (2007). Steady-state and inflammatory dendritic-cell development. Nat. Rev. Immunol. 7, 19-30.

Shrimpton, R. E., Butler, M., Morel, A. S., Eren, E., Hue, S. S., and Ritter, M. A. (2009). CD205 (DEC-205): a recognition receptor for apoptotic and necrotic self. Mol. Immunol. 46, 1229-1239.

Strobl, H., and Knapp, W. (1999). TGFbetal regulation of dendritic cells. Microbes Infect. 1, 1283-1290.

Stuart, L. M., Lucas, M., Simpson, C., Lamb, J., Savill, J., and Lacy-Hulbert, A. (2002). Inhibitory effects of apoptotic cell ingestion upon endotoxindriven myeloid dendritic cell maturation. J. Immunol. 168, 1627-1635.

Suzuki, S., Honma, K., Matsuyama, T., Suzuki, K., Toriyama, K., Akitoyo, I., Yamamoto, K., Suematsu, T., Nakamura, M., Yui, K., and Kumatori, A. (2004). Critical roles of interferon regulatory factor 4 in CD11bhighCD8alpha- dendritic cell development. Proc. Natl. Acad. Sci. U.S.A. 101, 8981-8986.

Tailor, P., Tamura, T., Morse, H. C. III, and Ozato, K. (2008). The BXH2 mutation in IRF8 differentially impairs dendritic cell subset development in the mouse. Blood 111, 1942-1945.

Tosello, V., Zamarchi, R., Merlo, A., Gorza, M., Piovan, E., Mandruzzato, S., Bronte, V., Wang, X., Ferrone, S., Amadori, A., and Zanovello, P. (2009). Differential expression of constitutive and inducible proteasome subunits in human monocytederived DC differentiated in the presence of IFN-alpha or IL-4. Eur. J. Immunol. 39, 56-66.

Tran, K. K., and Shen, H. (2009). The role of phagosomal $\mathrm{pH}$ on the size-dependent efficiency of crosspresentation by dendritic cells. Biomaterials 30, 1356-1362.

Trinchieri, G. (2003). Interleukin-12 and the regulation of innate resistance and adaptive immunity. Nat. Rev. Immunol. 3, 133-146.

Trinchieri, G., Pflanz, S., and Kastelein, R. A. (2003). The IL-12 family of heterodimeric cytokines: new players in the regulation of $\mathrm{T}$ cell responses. Immunity 19, 641-644.

Trombetta, E. S., Ebersold, M., Garrett, W., Pypaert, M., and Mellman, I. (2003). Activation of lysosomal function during dendritic cell maturation. Science 299, 1400-1403.

Vieira, O. V., Botelho, R. J., and Grinstein, S. (2002). Phagosome maturation: aging gracefully. Biochem. J. 366, 689-704.

Voll, R. E., Herrmann, M., Roth, E. A., Stach, C., Kalden, J. R., and Girkontaite, I. (1997). Immunosuppressive effects of apoptotic cells. Nature 390, 350-351.

Vremec, D., O’Keeffe, M., Hochrein, H., Fuchsberger, M., Caminschi, I., Lahoud, M., and Shortman, K. (2007). Production of interferons by 
dendritic cells, plasmacytoid cells, natural killer cells, and interferonproducing killer dendritic cells. Blood 109, 1165-1173.

Vremec, D., Pooley, J., Hochrein, H., Wu, L., and Shortman, K. (2000). CD4 and CD8 expression by dendritic cell subtypes in mouse thymus and spleen. J. Immunol. 164, 2978-2986.

Vremec, D., and Shortman, K. (1997). Dendritic cell subtypes in mouse lymphoid organs: cross-correlation of surface markers, changes with incubation, and differences among thymus, spleen, and lymph nodes. J. Immunol. 159, 565-573.

Weih, F., Carrasco, D., Durham, S. K., Barton, D. S., Rizzo, C. A., Ryseck, R. P., Lira, S. A., and Bravo, R. (1995). Multiorgan inflammation and hematopoietic abnormalities in mice with a targeted disruption of RelB, a member of the
NF-kappa B/Rel family. Cell 80, 331-340.

Wilson, N. S., El-Sukkari, D., Belz, G. T., Smith, C. M., Steptoe, R. J., Heath, W. R., Shortman, K., and Villadangos, J. A. (2003). Most lymphoid organ dendritic cell types are phenotypically and functionally immature. Blood 102, 2187-2194.

Wu, L., D’Amico, A., Winkel, K. D., Suter, M., Lo, D., and Shortman, K. (1998). RelB is essential for the development of myeloid-related CD8alpha- dendritic cells but not of lymphoid-related CD8alpha+ dendritic cells. Immunity 9, 839-847.

Wu, L., and Liu, Y. J. (2007). Development of dendritic-cell lineages. Immunity 26, 741-750.

Wu, L., Nichogiannopoulou, A., Shortman, K., and Georgopoulos, K. (1997). Cell-autonomous defects in dendritic cell populations of
Ikaros mutant mice point to a developmental relationship with the lymphoid lineage. Immunity 7 , 483-492.

Yamazaki, S., Dudziak, D., Heidkamp, G. F., Fiorese, C., Bonito, A. J., Inaba K., Nussenzweig, M. C., and Steinman, R. M. (2008). CD8+ CD205+ splenic dendritic cells are specialized to induce Foxp3+ regulatory T cells J. Immunol. 181, 6923-6933.

Zeidler, R., Eissner, G., Meissner, P. Uebel, S., Tampe, R., Lazis, S., and Hammerschmidt, W. (1997). Downregulation of TAP1 in B lymphocytes by cellular and Epstein-Barr virusencoded interleukin-10. Blood 90, 2390-2397.

Conflict of Interest Statement: The authors declare that the research was conducted in the absence of any commercial or financial relationships that could be construed as a potential conflict of interest.

Received: 09 December 2011; accepted: 19 February 2012; published online: 14 March 2012.

Citation: Thacker RI and Janssen EM (2012) Cross-presentation of cellassociated antigens by mouse splenic dendritic cell populations. Front. Immun 3:41. doi: 10.3389/fimmu.2012.00041

This article was submitted to Frontiers in Antigen Presenting Cell Biology, a specialty of Frontiers in Immunology. Copyright (C) 2012 Thacker and Janssen. This is an open-access article distributed under the terms of the Creative Commons Attribution Non Commercial License which permits non-commercial use, distribution, and reproduction in other forums, provided the original authors and source are credited. 